\title{
Assessing the impact of climate change on wheat and sugarcane with the AquaCrop model along the Indus River Basin, Pakistan
}

\author{
J. Alvar-Beltrán ${ }^{\text {a, }}$, A. Heureux ${ }^{\text {a }}$, R. Soldan ${ }^{\mathrm{b}}$, R. Manzanas ${ }^{\mathrm{c}}$, B. Khan ${ }^{\mathrm{a}}$, A. Dalla Marta ${ }^{\mathrm{d}}$ \\ ${ }^{\text {a }}$ Food and Agriculture Organization (FAO) of the United Nations, Rome, Italy \\ ${ }^{\mathrm{b}}$ Department of Plant Sciences, University of Oxford, United Kingdom \\ ${ }^{\mathrm{c}}$ Meteorology Group, Departamento de Matemática Aplicada y Ciencias de la Computación, Universidad de Cantabria, Santander, Spain \\ d Department of Agriculture, Food, Environment and Forestry (DAGRI), University of Florence, Italy
}

\section{A R T I C L E I N F O}

Handling Editor - J.E. Fernández

\section{Keywords:}

Wheat

Sugarcane

Evaporation

Transpiration

Water use efficiency

Climate change impacts

\begin{abstract}
A B S T R A C T
Pakistan is among the most vulnerable regions to climate change impacts, in particular the agricultural areas found in the worlds' largest contiguous irrigation system, the Indus River Basin (IRB). This study assesses the impacts of two climate change scenarios (Representative Concentration Pathways-RCPs 4.5 and 8.5) on soil evaporation and transpiration rates, crop water productivity (CWP) and wheat and sugarcane yields over the 21st century, under two irrigation schedules (less/more frequent irrigation and higher/lower volume) for six locations along the Sindh and Punjab provinces. Maximum and minimum temperatures are projected to increase across the study area over the course of the 21st century. Additionally, precipitation is projected to increase (decrease) along the southernmost (northernmost) areas during the summer rainy season from June to September. To evaluate the crop-water productivity of wheat and sugarcane, we used the AquaCrop model in the six selected locations. For assessing the goodness of model validation and calibration, different statistical indicators are considered for comparing simulated and observed inter-annual yield variability (e.g. NRMSE of 12.4\% and $12.1 \%$ for wheat and sugarcane, average values of the calibration and validation process). Our results show that wheat yields are likely to remain constant over time across the study areas, whereas sugarcane yields are expected to experience a decline in the Sindh province and an exponential increase in the Punjab province up to 2080, then yields will start to decline. In addition, our results reveal that both crops perform better, in terms of CWP, under low frequent irrigation and higher volumes of water. Overall, the findings of this work also support policymakers and project developers to implement adaptation strategies to cope with changing environmental conditions in a country where pressure on water resources is expected to continue to grow.
\end{abstract}

\section{Introduction}

According to the Global Climate Risk Index, Pakistan is ranked 5th among the countries experiencing highest number of extreme weather events during the 1999-2018 period (Eckstein et al., 2019). While the impacts of the 2018-2019 drought and cold wave are still ongoing, August 2020 was considered the wettest year in record for Pakistan, affecting 77,000 ha of agricultural land mostly along the Sindh province. Concurrently, a desert locust outbreak affected 46 districts across major agricultural provinces of the IRB (WMO, 2020). As a result, the impacts of climate change are anticipated to have a considerable impact on the country's agri-food systems due to more frequent and severe heat-stress conditions as well as from changes in water availability, which are expected to shift the spatial boundaries of crops besides changing its productivity. While the country's population is estimated to increase from 216 to 338 million by 2050 compared to 2019 , climate change is likely to negatively affect crop productivity and ultimately increase food insecurity nationally (Tariq et al., 2014; UN, 2019). According to the national nutrition survey in $2018,37 \%$ of the population faced food insecurity, and this number is likely to rise if climate related impacts on the agriculture sector are not properly addressed (WFP, 2018). The agricultural sector contributes to $\sim 25 \%$ of the Gross Domestic Product (GDP), while irrigation accounts for up to $70 \%$ of water withdrawn as a percentage of total renewable resources; particularly along the IRB, where pressure on water resources and dependency ratio is highest (FAO, 2016). The IRB is the largest contiguous irrigation system in the

\footnotetext{
* Corresponding author.

E-mail address: jorge.alvarbeltran@fao.org (J. Alvar-Beltrán).
} 


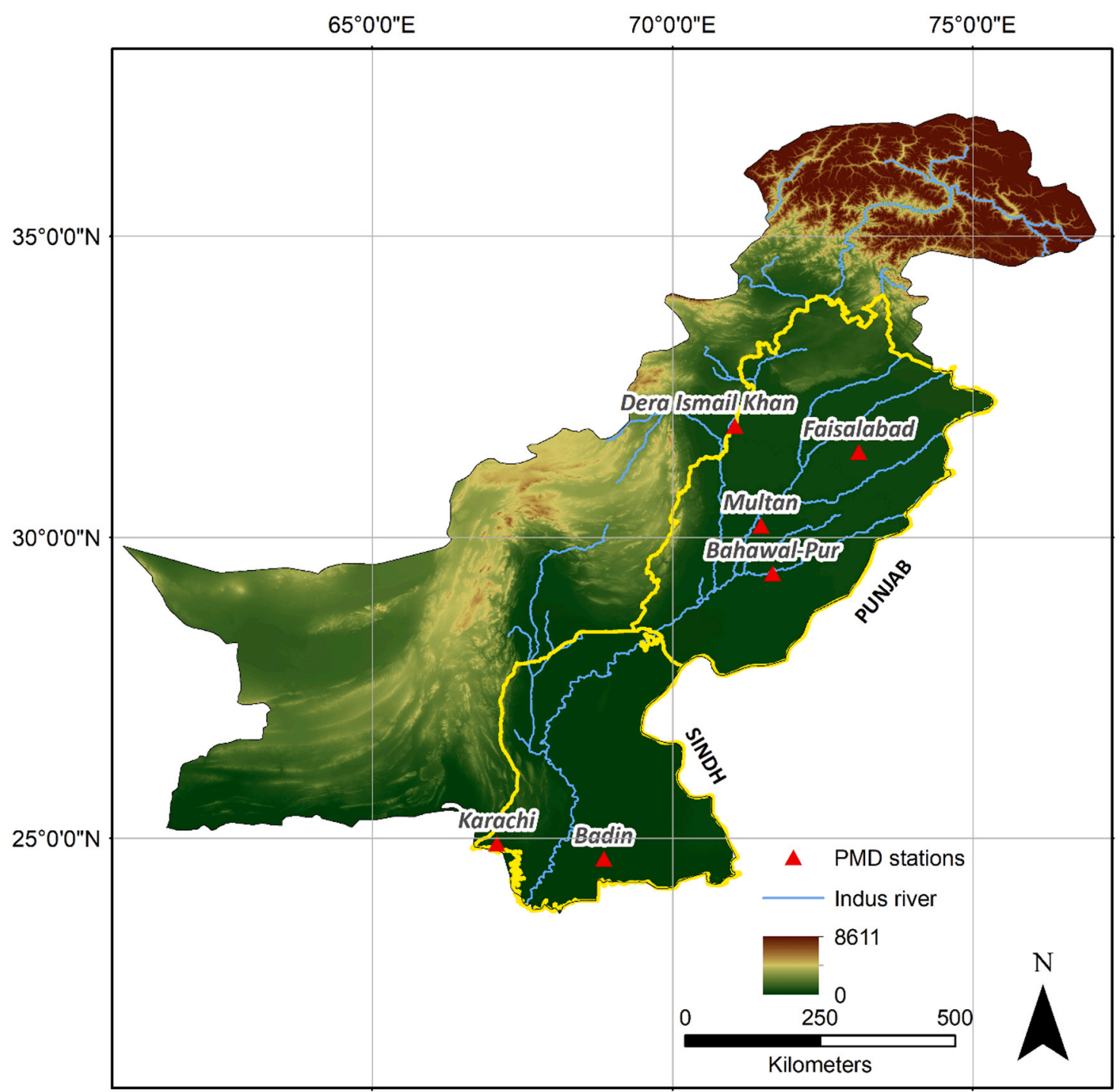

Fig. 1. Distribution of the weather stations across the Sindh and Punjab provinces.

world. However, the inter-annual variability of agricultural value added to the GDP and its high dependency on weather suggests that the IRB is among the most vulnerable regions to climate risks worldwide (TWB, 2016). Hence, there is a need to increase the understanding of future climate impacts on agricultural systems and implement measures to increase the efficiency and productivity of agricultural water use in response to climate change, growing demographic pressure and finite water resources (Richey et al., 2015).

Since 1960, the mean annual temperature in Pakistan has risen by $0.47^{\circ} \mathrm{C}$, with a projected increase of $3{ }^{\circ} \mathrm{C}$ by the end of the century relative to 1961-1990 (Chaudhry et al., 2009). Total annual precipitation is more erratic over large parts of Pakistan when compared to the historical average, with increasing number of intensified climatological and hydrological events, e.g. droughts and flooding (Houze et al., 2011; Adnan et al., 2016; Du et al., 2019). In Pakistan, precipitation changes are driven by the heating of the Tibetan Plateau, which forces monsoon variability within the region (Hijioka et al., 2014; Wang et al., 2019). The drivers (greenhouse gases) and impacts of climate change (rainfall variability and increasing temperatures) are projected to evolve with time, thereby determining their effect on plant's phenology and yield production is likely to become more complex into the future (Liancourt et al., 2012; Poulter et al., 2013).

In 2018, Pakistan reported harvested areas for wheat and sugarcane of 8.80 and 1.10 million hectares (ha) (equivalent to $47 \%$ of the country's total agricultural land), respectively, and yields of 2.85 and 60.96 tons ( $t)$ ha $^{-1}$ (FAO, 2018). Various studies have examined the effect of high temperature thresholds for these two crops. The optimal and maximum temperature thresholds of wheat's different phenological phases are: $22.0 / 32.7{ }^{\circ} \mathrm{C}$ emergence, $4.9 / 15.7{ }^{\circ} \mathrm{C}$ vernalization, $21.0 / 31.0{ }^{\circ} \mathrm{C}$ anthesis, and $20.7 / 35.4{ }^{\circ} \mathrm{C}$ grain-filling phase, respectively (Porter and Gawith, 1999). Additional studies looking at the effect of changes in temperatures $\left(+3,+4\right.$ and $\left.+5^{\circ} \mathrm{C}\right)$ and precipitation $(+10$ and $-10 \%$ ) with doubling $\mathrm{CO}_{2}$ concentrations conclude that wheat yields are likely to remain similar to current levels by 2060 (Janjua et al., 2010). In addition, sugarcane's ( $C_{4}$ crop) optimal growing temperatures range between 33 and $38{ }^{\circ} \mathrm{C}$, displaying a higher sensitivity to heat-stress conditions though having a higher temperature optimum when compared to $\mathrm{C}_{3}$ crops (Sanghera et al., 2019; Wahid and Close, 2007). Not only the difference in temperature optimum but the different mechanisms for fixing $\mathrm{CO}_{2}$ into biomass between $\mathrm{C}_{3}$ and $\mathrm{C}_{4}$ plants is another distinct physiological response, which can, among crops having a rapid stomata closure, translate into a reduction of water loss. Although increases in atmospheric $\mathrm{CO}_{2}$ and air temperatures can be beneficial for $\mathrm{C}_{3}$ crops (wheat), increasing temperatures are expected to result in higher water requirements due to increasing evapotranspiration rates (Kimball, 1983; Bowes, 1991; Poorter, 1993). Climate change 
is projected to have a negative impact on $\mathrm{C}_{4}$ crops, mainly grown along tropical and subtropical regions (Zhao and Li, 2015). For instance, in Pakistan, the yields of sugarcane are expected to decrease by $10 \%$ for every $1{ }^{\circ} \mathrm{C}$ increase (Afghan and Ijaz, 2015).

Crop models are useful tools for assessing water-limited crop yields under a wide range of environmental and management conditions. For instance, the AquaCrop model is a crop water productivity model that can be run with future meteorological data, together with projected $\mathrm{CO}_{2}$ levels, for assessing crop's responses to future climatic conditions (Vanuytrecht and Raes, 2011). In Pakistan, the AquaCrop model has already been used to examine the impacts of water management on salinization along cultivated areas of Faisalabad (Macaigne et al., 2018). Simulations with AquaCrop on sugar beet production under different irrigation schedules, mulching conditions and furrow systems have also been run along semi-arid regions of Pakistan (Malik et al., 2017). Additionally, the SWAP93 model has been used to simulate the soil water balance of sugarcane in order to develop an efficient irrigation scheduling for the Sindh province (Qureshi et al., 2002).

To date, there are not yet any studies assessing the combined effect of changing temperatures and precipitation, and elevated $\mathrm{CO}_{2}$ concentrations on the performance of wheat and sugarcane using the AquaCrop model in Pakistan. For sugarcane, Farooq and Gheewala (2020) have assessed the second growing season of sugarcane, but not the first growing season as done in this study. The present study calibrates and validates the AquaCrop model and evaluates the impacts of changing temperature and precipitation patterns on crops performance in terms of soil evaporation, transpiration, CWP and yield. Given that the IRB is the largest irrigation system in the world and is considered a vulnerable region to climate risks, this study focuses on the Sindh and Punjab provinces. Additional practical applications of this study include the development of different irrigation schedules for maximizing crop production across these two provinces.

\section{Materials and methods}

\subsection{Site description}

The Sindh and Punjab provinces are located within the IRB and along the easternmost parts of Pakistan, bordering India (Fig. 1). The climate along low-lying areas is characterized as semi-arid (100-500 mm/year) with warm mean annual temperatures $\left(25^{\circ} \mathrm{C}\right)$. Towards the northern parts of the Punjab province, the climate becomes milder, reaching dry winter and hot summer conditions towards the foothills of the Himalaya's. The IRB covers approximately half million $\mathrm{km}^{2}$ of Pakistan (65\%), particularly along the Sindh and Punjab provinces, to finally flow out into the Arabian Sea. Due to the long-term deposition of sediments, old alluvial soils are found along the Sindh and Punjab provinces. These types of soils, mainly loam, give the IRB one of the richest soil types and suitable growing conditions for a myriad of crops.

\subsection{AquaCrop input requirements}

\subsubsection{Weather data inputs}

Local projections of precipitation, maximum and minimum temperature were obtained from six weather stations within the network of the Pakistan Meteorological Department (PMD). The latter information was used in this work by means of statistical downscaling (SD), which allows to translate the low spatial resolution of the global climate simulations provided by Earth System Models (ESMs) to the local/regional scale needed for climate impact assessments. SD was performed following the Perfect Prognosis approach, under which a statistical model was calibrated by defining the relationship between local-scale observations (e. g. precipitation) and a set of quasi-observed large-scale atmospheric predictors (e.g. sea level pressure or winds) from a reanalysis over a historical period. Subsequently, the model was applied to the coarse ESM predictors (as given by different future emission scenarios) to
Table 1

List of Coupled Model Intercomparison Project Phase 5 (CMIP5) Earth System Models used in this study.

\begin{tabular}{lll}
\hline $\begin{array}{l}\text { CMIP5 } \\
\text { Model ID }\end{array}$ & $\begin{array}{l}\text { Atmospheric resolution (latitude } \\
\text { and longitude) }\end{array}$ & $\begin{array}{l}\text { Ocean resolution (latitude } \\
\text { and longitude) }\end{array}$ \\
\hline $\begin{array}{l}\text { MPI-ESM- } \\
\text { MR }\end{array}$ & $0.4^{\circ} \times 0.4^{\circ}$ & $1.9^{\circ} \times 1.9^{\circ}$ \\
CAN-ESM2 & $1.4^{\circ} \times 0.9^{\circ}$ & $2.8^{\circ} \times 2.8^{\circ}$ \\
CNRM-CM5 & $1.0^{\circ} \times 0.8^{\circ}$ & $1.4^{\circ} \times 1.4^{\circ}$ \\
NOR-ESM1 & $1.1^{\circ} \times 0.6^{\circ}$ & $2.5^{\circ} \times 1.9^{\circ}$ \\
\hline
\end{tabular}

Table 2

List of crop parameters used for the calibration of wheat and sugarcane.

\begin{tabular}{|c|c|c|c|c|c|}
\hline \multirow[b]{2}{*}{ Description } & \multirow[b]{2}{*}{ Units } & \multicolumn{2}{|l|}{ Wheat } & \multicolumn{2}{|l|}{ Sugarcane } \\
\hline & & Observed & Calibrated & Observed & Calibrated \\
\hline Sowing & $\begin{array}{l}\mathrm{dd} / \\
\mathrm{mm}\end{array}$ & & & & \\
\hline Badin (Sindh) & & $01 / 11$ & $01 / 11$ & $01 / 09$ & $01 / 10$ \\
\hline $\begin{array}{l}\text { Multan } \\
\text { (Punjab) }\end{array}$ & & $01 / 11$ & $01 / 11$ & $01 / 09$ & $01 / 10$ \\
\hline \multicolumn{6}{|l|}{$\begin{array}{l}\text { Crop } \\
\quad \text { development }\end{array}$} \\
\hline Plant density & $\begin{array}{l}\text { plants } \\
\mathrm{m}^{2}\end{array}$ & $150-300$ & 200 & $8-10$ & 10 \\
\hline $\begin{array}{l}\text { Planting } \\
\text { method }\end{array}$ & & $\begin{array}{l}\mathrm{D}, \mathrm{B}, \mathrm{R}, \\
\mathrm{ZT}\end{array}$ & DS & $\mathrm{R}, \mathrm{FS}$ & $\mathrm{T}$ \\
\hline $\begin{array}{l}\text { Time to max. } \\
\text { canopy cover }\end{array}$ & $\begin{array}{l}\text { days/ } \\
\text { GDD }\end{array}$ & $50-70$ & $51 / 960$ & $120-270$ & 159 \\
\hline $\begin{array}{l}\text { Maximum } \\
\text { canopy cover }\end{array}$ & $\%$ & $85-90$ & 86 & $85-90$ & 98 \\
\hline $\begin{array}{l}\text { Time to } \\
\text { flowering }\end{array}$ & $\begin{array}{l}\text { days/ } \\
\text { GDD }\end{array}$ & $\begin{array}{l}80-120 / \\
1300\end{array}$ & $72 / 1368$ & $270-300$ & - \\
\hline $\begin{array}{l}\text { Duration of } \\
\text { flowering }\end{array}$ & GDD & $150-280$ & 228 & $60-120$ & - \\
\hline $\begin{array}{l}\text { Time to } \\
\text { senescence }\end{array}$ & $\begin{array}{l}\text { days/ } \\
\text { GDD }\end{array}$ & $\begin{array}{l}100-120 / \\
2000\end{array}$ & $100 / 1900$ & - & 194 \\
\hline $\begin{array}{l}\text { Physiological } \\
\text { maturity }\end{array}$ & $\begin{array}{l}\text { days/ } \\
\text { GDD }\end{array}$ & $\begin{array}{l}140-170 / \\
2900\end{array}$ & $155 / 2945$ & $270-365$ & 215 \\
\hline \multicolumn{6}{|l|}{ Crop production } \\
\hline Harvest index & $\%$ & $45-50$ & 47 & $25-40$ & 50 \\
\hline
\end{tabular}

Legend: D (drill sowing), B (broadcasting), R (ridges), ZT (zero tillage), FS (furrow sowing), DS (direct sowing), T (transplanting), DAS (days after sowing), GDD (growing degree days). Note that the calibration of sugarcane was done on DAS rather than GDD.

obtain the corresponding (local) downscaled climate change projections for the future (see Manzanas et al. 2020 and references therein). For the calibration phase, ERA-Interim reanalysis (Dee et al. 2011) were used. For the projection phase, four ESMs from the Coupled Model Intercomparison Project Phase 5 (CMIP5) (Table 1) were considered, under two Representative Concentration Pathways (RCPs) accounting for different socio-economic and future emission scenarios, namely the RCP4.5 and the RCP8.5, $\sim 550$ and $\sim 1000$ CO2 ppm by 2100 respectively (Clarke et al. 2007; Riahi et al. 2007).

To downscale precipitation, the present study used the nearest analog technique (Zorita et al. 1995), in which the local values for any future atmospheric configuration (as given by ESM predictors) were estimated from the local observations corresponding to most similar (or analog) historic configuration (as represented by ERA-Interim). Alternatively, to downscale maximum and minimum temperature, a multiple linear regression (MLR) was applied, an extension of simple linear regression that attempts to model the relationship between predictors and a response variable (e.g. predictand) by fitting a linear equation to the observed data. The fit is determined here, based on ERA-Interim predictors, by minimizing the sum of the residuals between the regression line and the observed data (Helsel and Hirsch, 2002). The analog technique was not suitable for temperatures given its inability to extrapolate values out of the observed range in the historical period, 


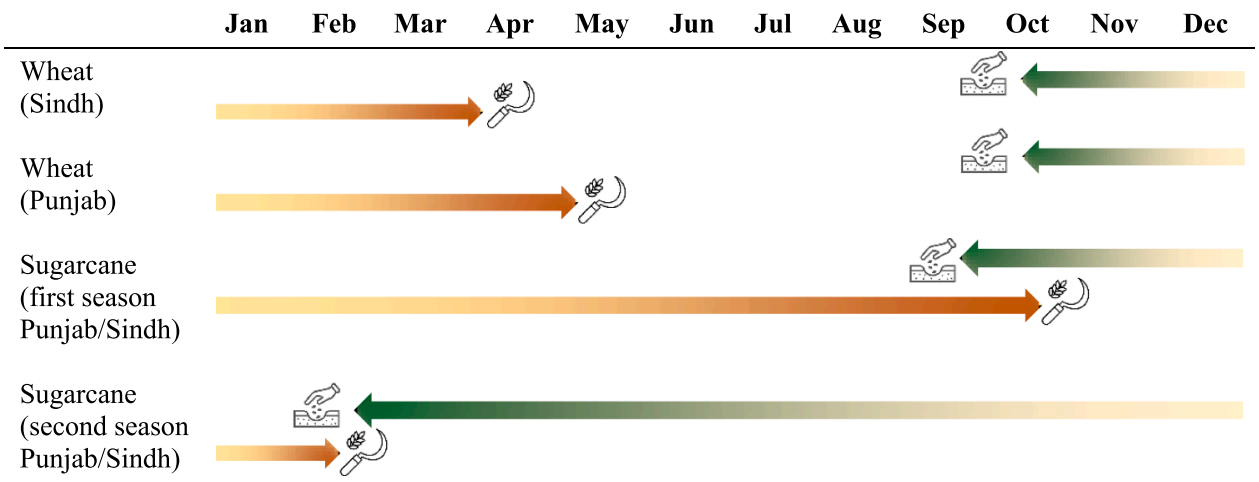

Fig. 2. Approximate crop calendars for wheat and sugarcane along the Sindh and Punjab provinces.

which may constitute an important issue in the context of a changing climate (Gutiérrez et al. 2013). For precipitation (temperatures), the leading 30 (15) principal components (Preisendorfer and Mobley, 1988) of a combination of sea level pressure, geopotential height at $250 \mathrm{hPa}$, temperature, meridional winds and relative humidity at $850 \mathrm{hPa}$ - which are the main drivers of the local climate - were used as predictors in this work. These were defined over a $2^{\circ}$ regular grid covering the domain $60-78^{\circ} \mathrm{E}, 23-37^{\circ} \mathrm{N}$.

\subsubsection{Crop and soil information inputs}

Historical yield data (2006-2015) for wheat and sugarcane was provided by the Ministry of National Food Security and Research (MNFSR) for two locations, Badin (Sindh) and Multan (Punjab). Additional information on management practices (e.g. sowing and harvesting date and sowing method) and crop development parameters (e.g. time and duration of flowering, maximum canopy cover, physiological maturity) were shared by the MNFSR for the Sindh and Punjab provinces (Table 2). The cane fresh yield was converted into dry yield by, first, calculating the stalk dry weight (fresh weight *0.30), which was then added to the proportion of trash dry weight ( $0.65 *$ stalk dry weight), as calculated from Thompson (1978) and later modified by Irvine (1983). The crop calendars of wheat and sugarcane along the Sindh and Punjab provinces were shown in Fig. 2. While there was only one growing season for wheat (Nov-Apr), sugarcane was either planted in fall (Sep-Oct) or just before the start of the spring (Feb-Mar). However, in the present study, only the first sowing season was analyzed (Sep-Oct). The soil texture information for each location was retrieved from research literature, having Badin and Multan loam and clay-loam soil textures, respectively (ISRIC, 2020; UAF, 2020).

\subsection{The AquaCrop model}

The FAO AquaCrop model simulates crop yield in different steps: (i) crop development, (ii) crop transpiration, (iii) biomass production, and (iv) yield formation. The calculation of evapotranspiration within the model is divided into transpiration and soil evaporation. Transpiration is directly related to the canopy cover (CC), whereas evaporation is proportional to the bare soil. For calculating the potential crop transpiration, the CC is multiplied by the reference evapotranspiration (ETo), determined by the FAO-56 Penman-Monteith equation, and by the crop coefficient (Kc). Then, the actual transpiration (Ta) is calculated from potential evapotranspiration. In addition, Ta is used for calculating crop biomass (B), which is computed by multiplying actual transpiration by the water productivity (WP) (Eq. (1)). The harvest index (HI) allows to obtain the crop yield (Y) by the crop biomass (B) (Eq. (2)) (Raes et al., 2018).

Crop biomass (B) as kg/ha $=\sum T a^{*} W P$

Crop yield $(\mathrm{Y})$ as $\mathrm{kg} / \mathrm{ha}=H I^{*} B$
Table 3

Irrigation schedules and total amount irrigation applied for the calibration, validation and future simulations of wheat and sugarcane on AquaCrop.

\begin{tabular}{|c|c|c|c|c|}
\hline Location (s) & Scenarios & $\begin{array}{l}\text { Frequency } \\
\text { (days) }\end{array}$ & $\begin{array}{l}\text { Amount } \\
(\mathrm{mm})\end{array}$ & $\begin{array}{l}\text { Total } \\
(\mathrm{mm})\end{array}$ \\
\hline \multicolumn{5}{|l|}{ Wheat } \\
\hline Badin (calibration) & $\begin{array}{l}\text { Past } \\
\text { (2006-2015) }\end{array}$ & 7 & 10 & 200 \\
\hline $\begin{array}{l}\text { Multan (validation dry } \\
\text { years) }\end{array}$ & $\begin{array}{l}\text { Past } \\
(2006-2015)\end{array}$ & 5 & 9 & 306 \\
\hline $\begin{array}{l}\text { Multan (validation wet } \\
\text { years) }\end{array}$ & $\begin{array}{l}\text { Past } \\
(2006-2015)\end{array}$ & 7 & 13 & 319 \\
\hline Badin and Karachi & $\begin{array}{l}\text { Future } \\
(2010-2100)\end{array}$ & 7 & 10 & 200 \\
\hline Badin and Karachi & $\begin{array}{l}\text { Future } \\
(2010-2100)\end{array}$ & 8 & 14 & 245 \\
\hline $\begin{array}{l}\text { Multan, Faisalabad, } \\
\text { Dera Ismail Khan, } \\
\text { and Bahawal-Pur }\end{array}$ & $\begin{array}{l}\text { Future } \\
(2010-2100)\end{array}$ & 5 & 10 & 284 \\
\hline $\begin{array}{l}\text { Multan, Faisalabad, } \\
\text { Dera Ismail Khan, } \\
\text { and Bahawal-Pur }\end{array}$ & $\begin{array}{l}\text { Future } \\
(2010-2100)\end{array}$ & 7 & 13 & 319 \\
\hline$\frac{\text { Sugarcane }}{\text { Badin (calibration) }}$ & $\begin{array}{l}\text { Past } \\
(2006-2015)\end{array}$ & 7 & 29 & 870 \\
\hline Multan (validation) & $\begin{array}{l}\text { Past } \\
(2006-2015)\end{array}$ & 10 & 41 & 861 \\
\hline Badin and Karachi & $\begin{array}{l}\text { Future } \\
(2010-2100)\end{array}$ & 7 & 29 & 870 \\
\hline $\begin{array}{l}\text { Multan, Faisalabad, } \\
\text { Dera Ismail Khan, } \\
\text { and Bahawal-Pur }\end{array}$ & $\begin{array}{l}\text { Future } \\
(2010-2100)\end{array}$ & 10 & 41 & 861 \\
\hline
\end{tabular}

\subsubsection{Simulation outputs}

The yearly evapotranspiration (ET) was determined by the AquaCrop model using the FAO-56 Penman-Monteith method (Allen et al., 1998) for RCPs 4.5 and 8.5 and two irrigation schedules (Table 3) for the six PMD stations (Fig. 1) over the 21 st century. The analysis of vegetation transpiration (T) and soil evaporation (SE) was conducted separately, as each of these variables could play a key role on determining the crop water productivity (CWP). The CWP (Eq. (3)) was used to describe the trade-offs between water loss and carbon sequestration in the plant photosynthesis and carbon assimilation process. Climatic factors affecting crop's potential evapotranspiration were assessed to describe the way specific temperature thresholds reduced the CWP due to increased rates of evapotranspiration. Then, sugarcane and wheat yields were examined to better understand if elevated atmospheric $\mathrm{CO}_{2}$ concentrations had a positive or negative impact on $\mathrm{C}_{3}$ and $\mathrm{C}_{4}$ plants by reducing photorespiration besides enhancing photosynthetic $\mathrm{CO}_{2}$ exchange. 


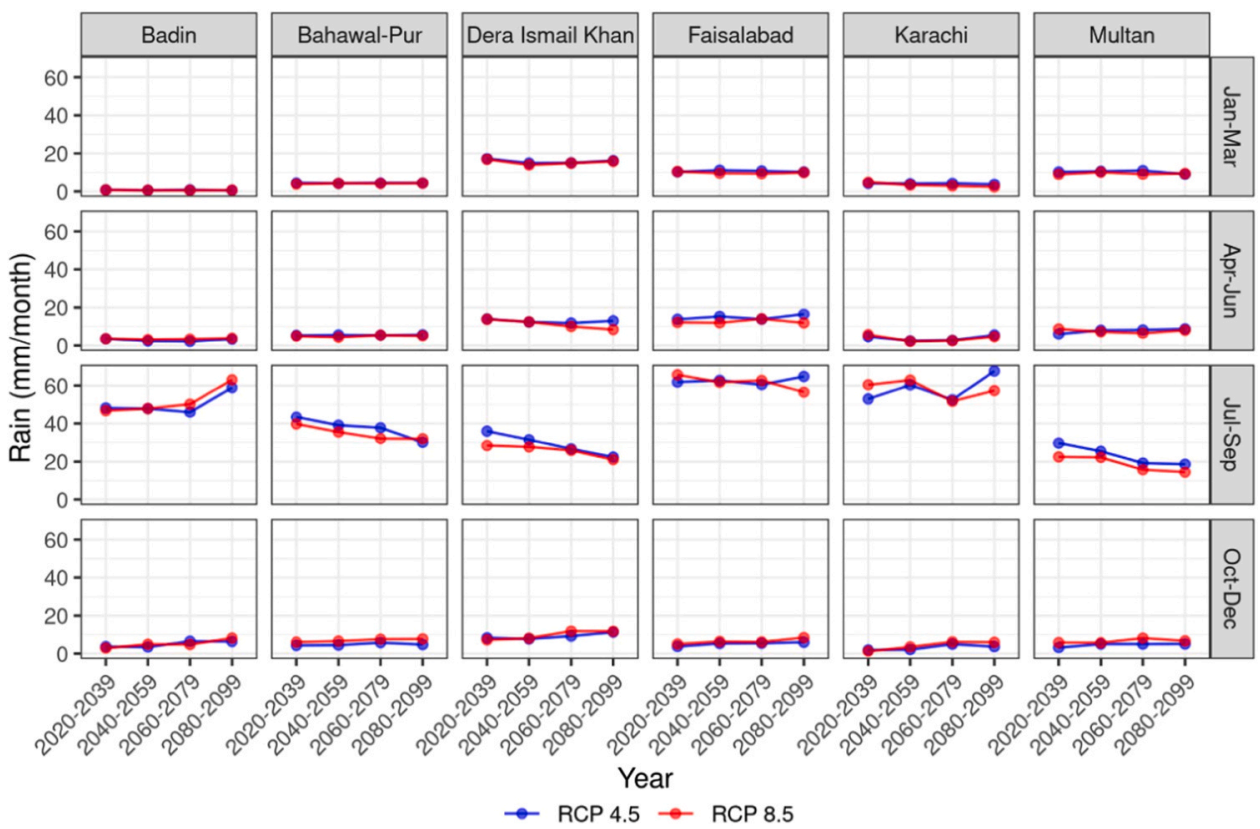

Fig. 3. Projected monthly precipitation under RCP 4.5 and 8.5 along the six locations considered in Sindh and Punjab (in columns) for different quarters of the year (in rows).

Crop Water Productivity $(\mathrm{CWP}) \mathrm{as} \mathrm{kg} / \mathrm{m} 3=\frac{B}{\left(\sum T r\right)}$

Where $B$ is the estimated above-ground biomass (in $\mathrm{kg}$ ) and $\sum \operatorname{Tr}$ the cumulative amount of water transpired (in $\mathrm{m}^{3}$ ), respectively.

\subsubsection{Calibration and validation of AquaCrop}

The FAO AquaCrop model was calibrated and validated using 10year yield data (2006-2015) of wheat and sugarcane for Badin (Sindh) and Multan (Punjab). Afterwards, annual-simulations were run until the end of the century using the downscaled meteorological inputs obtained from the ESMs under the two RCPs (4.5 and 8.5), two irrigation schedules (Table 3 ) and four additional locations (Fig. 1): one along the
Sindh province (Karachi) and three extra locations across the Punjab province (Faisalabad, Dera Ismail Khan, and Bahawal-Pur).

The AquaCrop's performance to simulate observed yield for the period 2006-2015 was evaluated using the standard and normalized root mean square errors (RMSE and NRMSE, respectively), mean absolute percentage error (MAPE) and Wilmott's Index of Agreement (d). The RMSE, NRMSE, MAPE and Wilmott's Index of Agreement were calculated as in Eqs. (4-7):

RMSE $=\sqrt{\frac{1}{n} \sum_{i=1}^{n}(O i-P i)^{2}}$

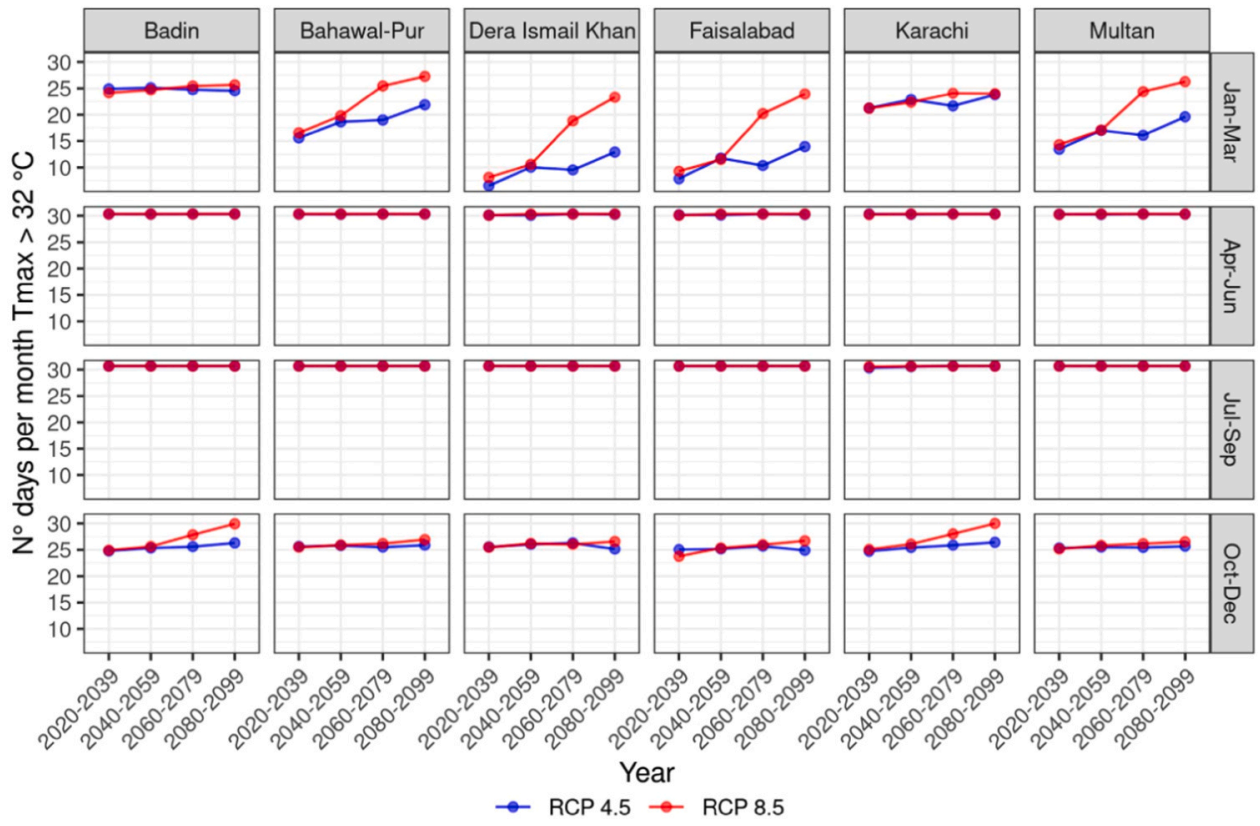

Fig. 4. Number of days per month with Tmax $>32{ }^{\circ} \mathrm{C}$ under RCP 4.5 and 8.5 for the six locations considered in Sindh and Punjab (in columns) provinces for different quarters of the year (in rows). 

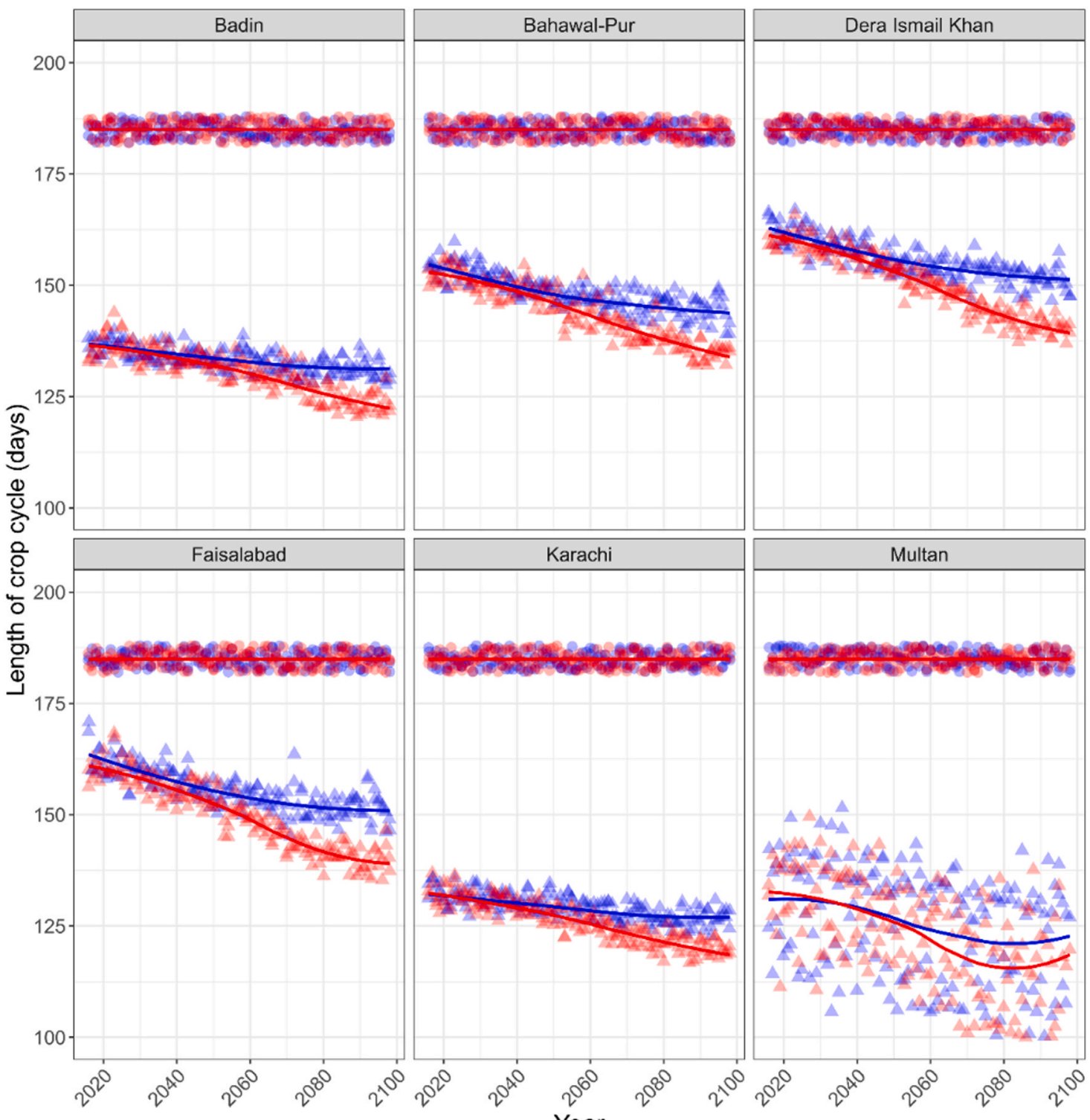

Year

$$
\text { - RCP } 4.5-\operatorname{RCP} 8.5 \quad \text { sugar cane } \triangle \text { Wheat }
$$

Fig. 5. Projected length of the growing cycle (in days) for wheat (triangles) and sugarcane (circles) under RCP 4.5 and 8.5 (blue and red, respectively) along the six locations considered in Sindh and Punjab provinces. (For interpretation of the references to color in this figure legend, the reader is referred to the web version of this article.)

$$
\begin{aligned}
& \text { NRMSE }=\frac{R M S E}{\widehat{O}} \times 100 \\
& \text { MAPE }=\sum_{i=1}^{n} \frac{(O i-P i)^{2}}{(O i)} \times 100 \\
& \mathrm{~d}=1-\frac{\sum_{i=1}^{n}(O i-P i)^{2}}{\sum_{i=1}^{n}\left(P_{i}^{\prime}+O_{i}^{\prime}\right)^{2}}
\end{aligned}
$$

Where $O_{i}$ and ${ }_{P i}$ corresponded to the observed and simulated values, respectively, $O^{\prime}{ }_{i}=\left[\mathrm{O}_{\mathrm{i}}-\widehat{\mathrm{O}}\right]$ and $P^{\prime}{ }_{i}=[\mathrm{Pi}-\widehat{\mathrm{P}}]$ showed the differences between an observed and/or simulated value with the observed and simulated means, and $n$ is the number of treatments. RMSE had the same units as that of the variable being simulated (ton $/ \mathrm{ha}^{-1}$ ), whereas NRMSE was expressed as a percentage. The closer the values were to zero the higher the model's performance. We considered that the AquaCrop model was well calibrated if the NRMSE was lower than $15 \%$ and highly performant if lower than 5\% (Raes et al., 2018).

\subsection{Irrigation schedules}

The generation of irrigation schedules was necessary to plan a potential irrigation strategy in the IRB, aiming at optimizing yields with lower applications of water. Although crop parameters and initial soil conditions remained similar for the validation of wheat, two irrigation schedules for the 2006-2015 period were proposed in order to best fit the observed inter-annual precipitation variability and its impacts on observed yields in Multan (Table 3). This was necessary under rainfed conditions, as sporadic heavy rains reported along the Punjab province disturbed the planned irrigation treatments. For that reason, the present study followed the approach of Sandhu et al. (2015) for rice along the Punjab region of India and that of Andarzian et al. (2011) for wheat in 

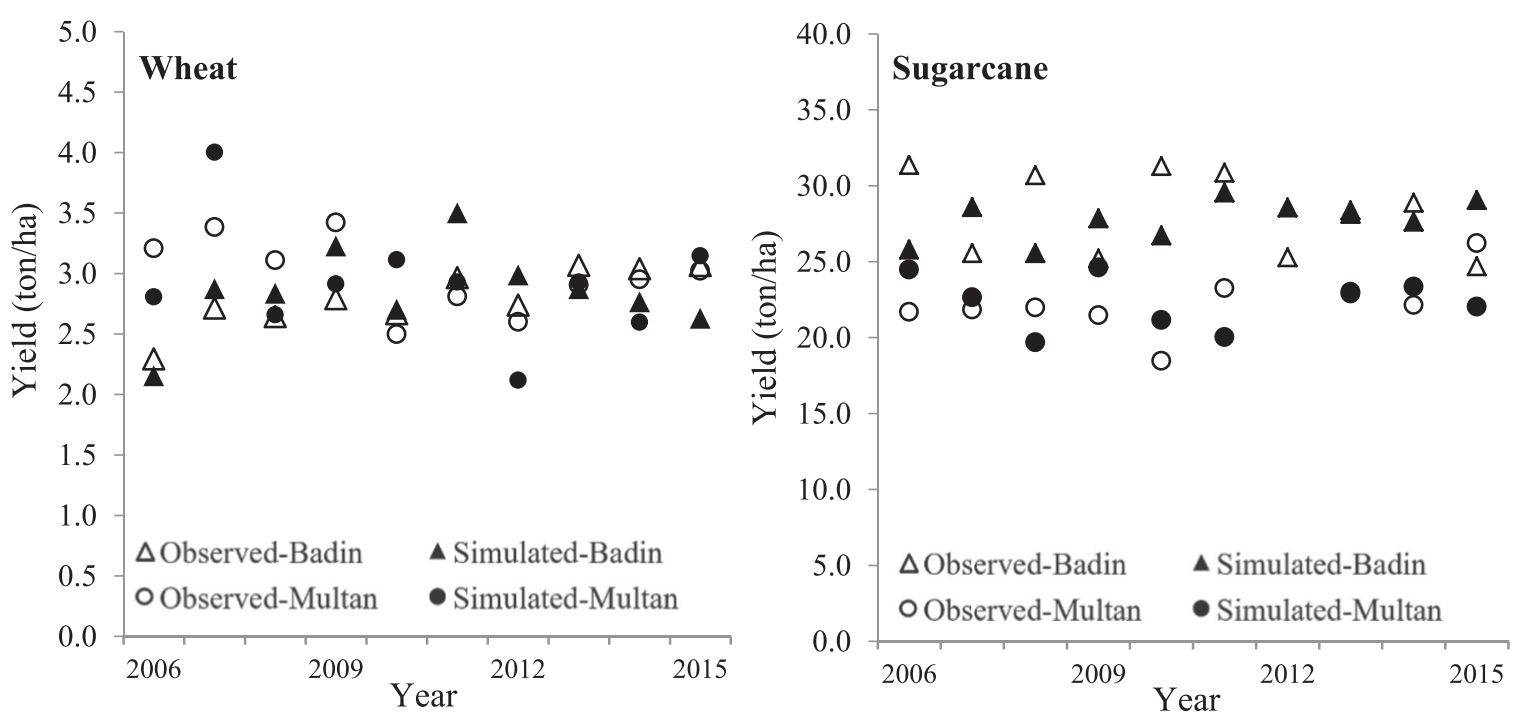

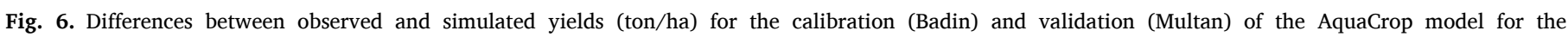
period 2006-2015.

RCP 8.5

RCP 4.5

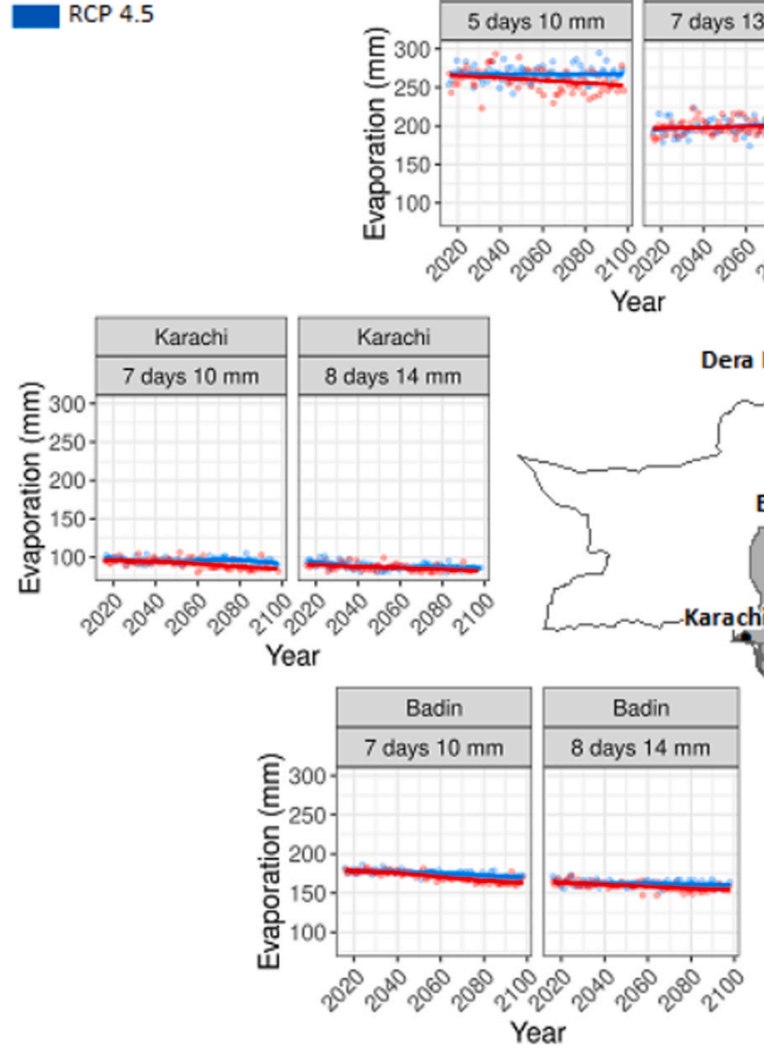

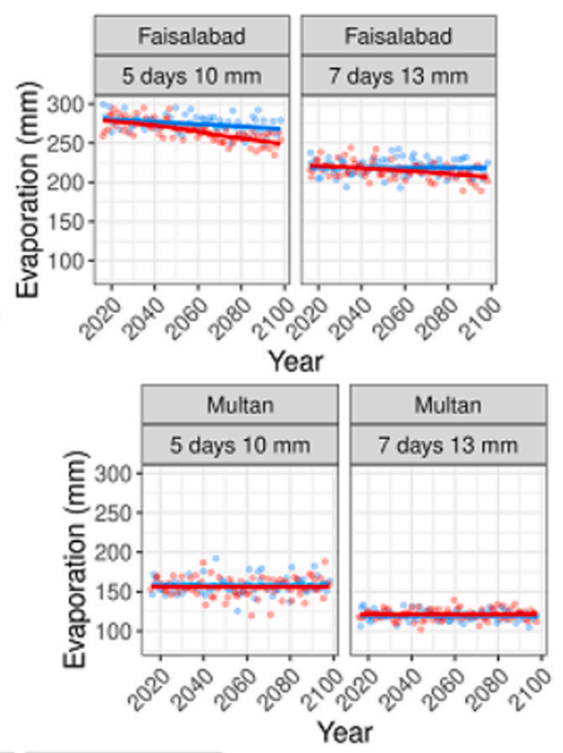

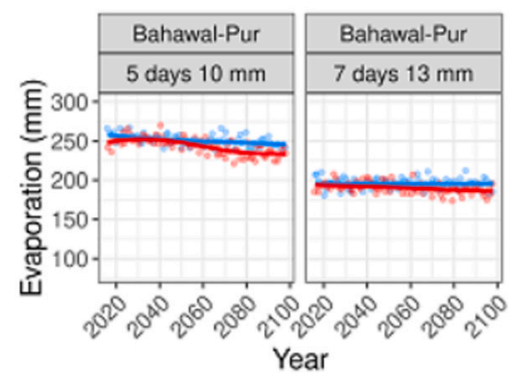

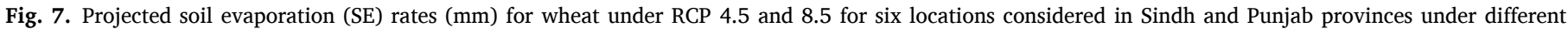
irrigation schedules.

Iran, with different irrigation scenarios according to the observed precipitation. While Sandhu et al. (2015) tested four different irrigation schedules for the validation of rice with AquaCrop, this work embraced two irrigation schedules for the validation of wheat in Multan. As a result, the present study defined different irrigation schedules based on the average precipitation observed $(77.8 \mathrm{~mm})$ during wheat's growing season in Multan during the 2006-2015 period. Therefore, $77.8 \mathrm{~mm}$ was considered the threshold between a drier or wetter than usual dry-season; consequently, triggering different types of irrigation schedules during the calibration process. In order to enhance the CWP and the economic yield per unit of water used by the crop, an additional irrigation schedule was proposed for Karachi (Sindh province). The irrigation method used both for the calibration and validation of wheat was surface irrigation on furrows and the time criteria was fixed intervals with a fixed net application.

For the calibration of sugarcane in Badin, the irrigation schedule was 

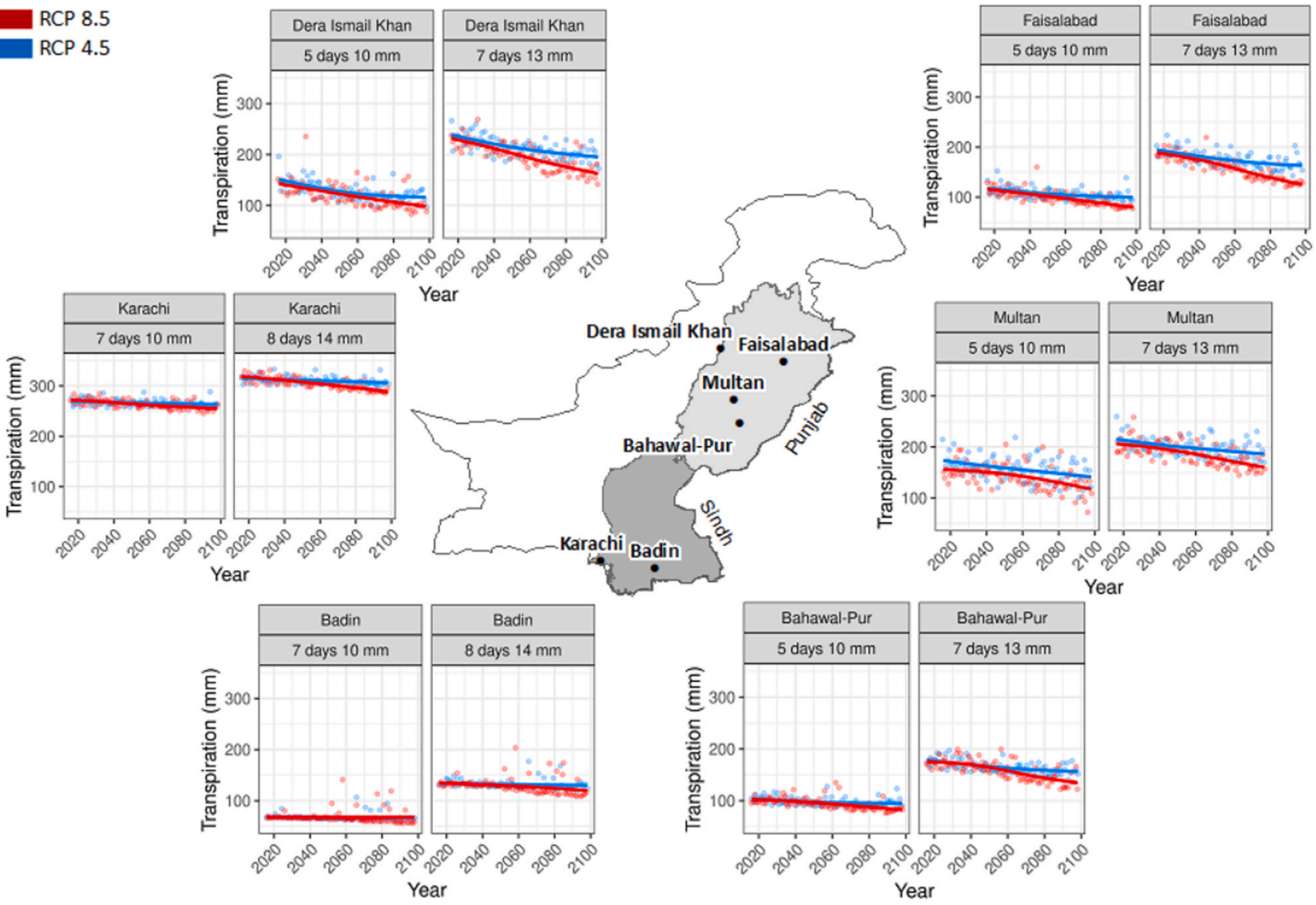

Fig. 8. Projected transpiration (T) rates (mm) for wheat under RCP 4.5 and 8.5 for six locations considered in Sindh and Punjab provinces under different irrigation schedules.

set every 7 days with $29 \mathrm{~mm}$ ( $870 \mathrm{~mm}$ in total); whereas for the validation, Multan, every 10 days with $41 \mathrm{~mm}$ (861 $\mathrm{mm}$ in total). Since these irrigation schedules had a similar amount of water application, they were both tested in future simulations to assess the CWP of sugarcane under changing climate conditions. For sugarcane, sprinkler irrigation was the method selected where $100 \%$ of the soil surface was watered at each irrigation event. The selected time criteria was fixed intervals with a fixed net application.

\section{Results}

\subsection{Climatic trends}

\subsubsection{Precipitation impacts on wheat and sugarcane}

The downscaled projections show a slight increase $(+2.7 \mathrm{~mm} /$ month) in average rainfall during Oct-Dec for the period 2080-2099 (as compared to 2020-2039) for both RCPs over the six locations (Fig. 3). Hence, rainfall changes are likely to have no impacts on early growing stages of wheat. A similar behavior is projected for flowering and maturity of wheat (Jan-Mar), with a small decrease $(-0.5 \mathrm{~mm} / \mathrm{month})$ in average rainfall during Jan-Mar for 2080-2099 (as compared to 2020-2039) for both RCPs over the six locations. Conversely, sugarcane will be affected at senescence by a notable decrease $(-10.2 \mathrm{~mm} / \mathrm{month})$ in average rainfall during Jul-Sep for 2080-2099 (as compared to 2020-2039) for both RCPs particularly along Bahawal-Pur, Dera Ismail Khan and Multan. On the contrary, Badin will experience an increase in precipitation $(+13.1 \mathrm{~mm} / \mathrm{month})$ over Jul-Sep.

\subsubsection{Temperature impacts on wheat and sugarcane}

Regarding critical temperature thresholds for crop development, all sites will experience a considerable increase in the number of days per month with maximum temperatures (Tmax) above $32{ }^{\circ} \mathrm{C}$. It is likely that early vegetative stages of wheat (Oct-Dec) will be affected by heat-stress conditions if sowing is carried out early in October $\left(32.7^{\circ} \mathrm{C}\right.$ is considered the maximum temperature threshold for wheat at emergence). For instance, in Karachi and Badin the number of days with Tmax above $32{ }^{\circ} \mathrm{C}$ will rise from 25 to 30 days per month by 2080-2099 (as compared to 2020-2039) under RCP 8.5 (Fig. 3). More importantly, wheat will be affected by heat-stress conditions if flowering occurs in March $\left(31.0^{\circ} \mathrm{C}\right.$ is considered the maximum threshold for wheat at anthesis). However, the current growing calendar shows that flowering of wheat currently occurs in January, when temperatures across all study areas are at its lowest. The highest temperature increase during mid-growing stages of wheat (Jan-Mar) is projected to occur over the Punjab province, where the average Tmax (mean of four locations) will likely increase from 25.6 to $29.8^{\circ} \mathrm{C}$ for $2080-2099$ (as compared to 2020-2039) under RCP 8.5. Even though the average Tmax will remain below $30{ }^{\circ} \mathrm{C}$ during Jan-Mar, it is projected that the number of days per month with Tmax above $32{ }^{\circ} \mathrm{C}$ will exceed 15 and 25 days/month respectively under RCP 4.5 and 8.5 by the end of the century. Furthermore, if the sowing date of wheat remains the same, it is likely that increasing temperatures will shorten the crop's growing cycle, hence reducing the probability of being affected by heat-stress conditions at flowering. In AquaCrop, the heat units were expressed as growing degree days (GDD) and increasing temperatures have demonstrated a key role on crop development. The previous is reflected in the emerging findings, where wheat is likely to reach maturity 20-30 days earlier at the end of the century when comparing the observed values for the 2006-2015 period (150 days) against the projected ones (Fig. 5). Additionally, sugarcane does not display any changes over time because 


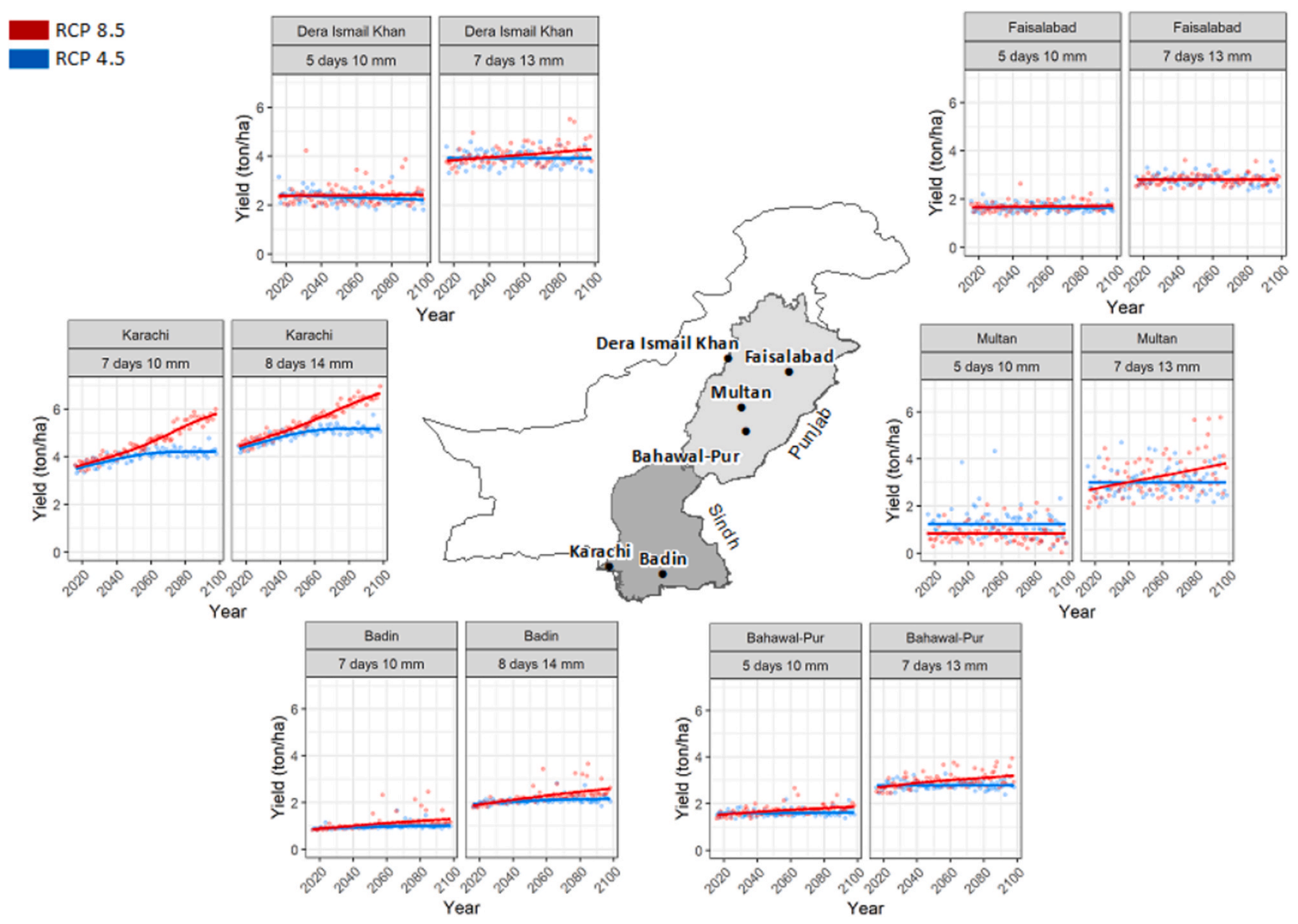

Fig. 9. Projected wheat yields (ton/ha) under RCP 4.5 and 8.5 for six locations considered in Sindh and Punjab provinces under different irrigation schedules.

of the type of calibration used for the crop parameters, in days after sowing (DAS) rather than in GDD (as done for wheat). Therefore, the length and duration of sugarcane's development stages were not adjusted to the temperature regimes of distinctive years and as a consquence do not display any changes over time.

For sugarcane, the highest temperature increase is expected to occur between Apr-Jun, when the average Tmax will likely rise from 40.9 to $43.5^{\circ} \mathrm{C}$ when comparing the $2020-2039$ and $2080-2099$ periods under both RCPs across the six locations. Hence, exceeding sugarcane's optimal growing temperatures established at $33-38^{\circ} \mathrm{C}$. The average Tmax during Oct-Dec will also experience a notable increase along the Sindh province, from 33.0 to $35.2^{\circ} \mathrm{C}$ when $2020-2039$ and $2090-2099$ periods are compared.

\subsection{Calibration and validation of AquaCrop}

The AquaCrop model was calibrated and validated for wheat and sugarcane based on the available yield information for Badin and Multan over the period 2006-2015. The calibration and validation results in AquaCrop for wheat yields were as follows: NRMSE 10.9\% and 13.9\%, RMSE 0.30 and $0.42 \mathrm{t} /$ ha, MAPE $9.3 \%$ and $12.44 \%$, and Wilmott's index of agreement (d) 0.96 both for the calibration and validation. Although AquaCrop slightly overestimated the observed wheat yields during the first half (2006-2010) of the calibration period $(-4.8 \%$ average difference between simulated and observed yields), the model was capable of simulating well the inter-annual variability of yields (Fig. 6) throughout the entire calibration period (2006-2015). Because of the high rainfall variability in Multan and its impacts on wheat yields, it was challenging for the model to simulate inter-annual yield fluctuations during the validation process in Badin. Furthermore, the calibration and validation results in AquaCrop for sugarcane were as follows: NRMSE $12.5 \%$ and $11.6 \%$, RMSE 3.57 and 2.59 t/ha, MAPE $11.2 \%$ and $10.2 \%$, and Wilmott's index of agreement (d) 0.89 and 0.90, respectively. Hence, for both crops, the statistics showed NRMSE values below $15 \%$, indicating a good calibration and validation of the AquaCrop model.

\subsection{Wheat}

\subsubsection{Soil evaporation and transpiration}

The present findings reveal a strong relationship between high soil evaporation (SE) and different irrigation schedules along the Punjab province. Although sites along the Punjab province ( 5 days $-10 \mathrm{~mm}$; total $270-297 \mathrm{~mm}$ ) received $50 \%$ additional irrigation than those found in the Sindh province (7 days-10 $\mathrm{mm}$; total $190-210 \mathrm{~mm}$ ), the SE values of Punjab province (Dera Ismail Khan; total SE $264 \mathrm{~mm}$ ) tripled those of Sindh province (Karachi; total SE $90 \mathrm{~mm}$ ), average of both RCPs (Fig. 7). Overall, soil evaporation rates behaved similarly under RCP 4.5 and 8.5, with a decreasing trend over time along Faisalabad, Bahawal-Pur, Karachi and Badin. For transpiration (T), T rates were lower under frequent and low irrigation volumes, with a moderate decrease in T rates overtime, being higher under RCP 8.5 when compared to RCP 4.5 (Fig. 8). The greatest T decline was reported in Dera Ismail Khan, from $236 \mathrm{~mm}$ in 2010-2019-161 mm in 2090-2099 under RCP 8.5. Large T differences were reported when averaging the long-time series of Karachi $(287 \mathrm{~mm})$ and Badin $(99 \mathrm{~mm})$ for different irrigation schedules under both RCPs. Finally, the effect of heat-stress was simulated in AquaCrop using the temperature stress coefficient for crop transpiration $\left(\mathrm{Ks}_{\mathrm{Tr}}\right)$. For wheat, the average temperature stress affecting crop transpiration was close to $0(0.07 \%$ of the growing period) for both RCPs, across all study areas and under different irrigation schemes. 

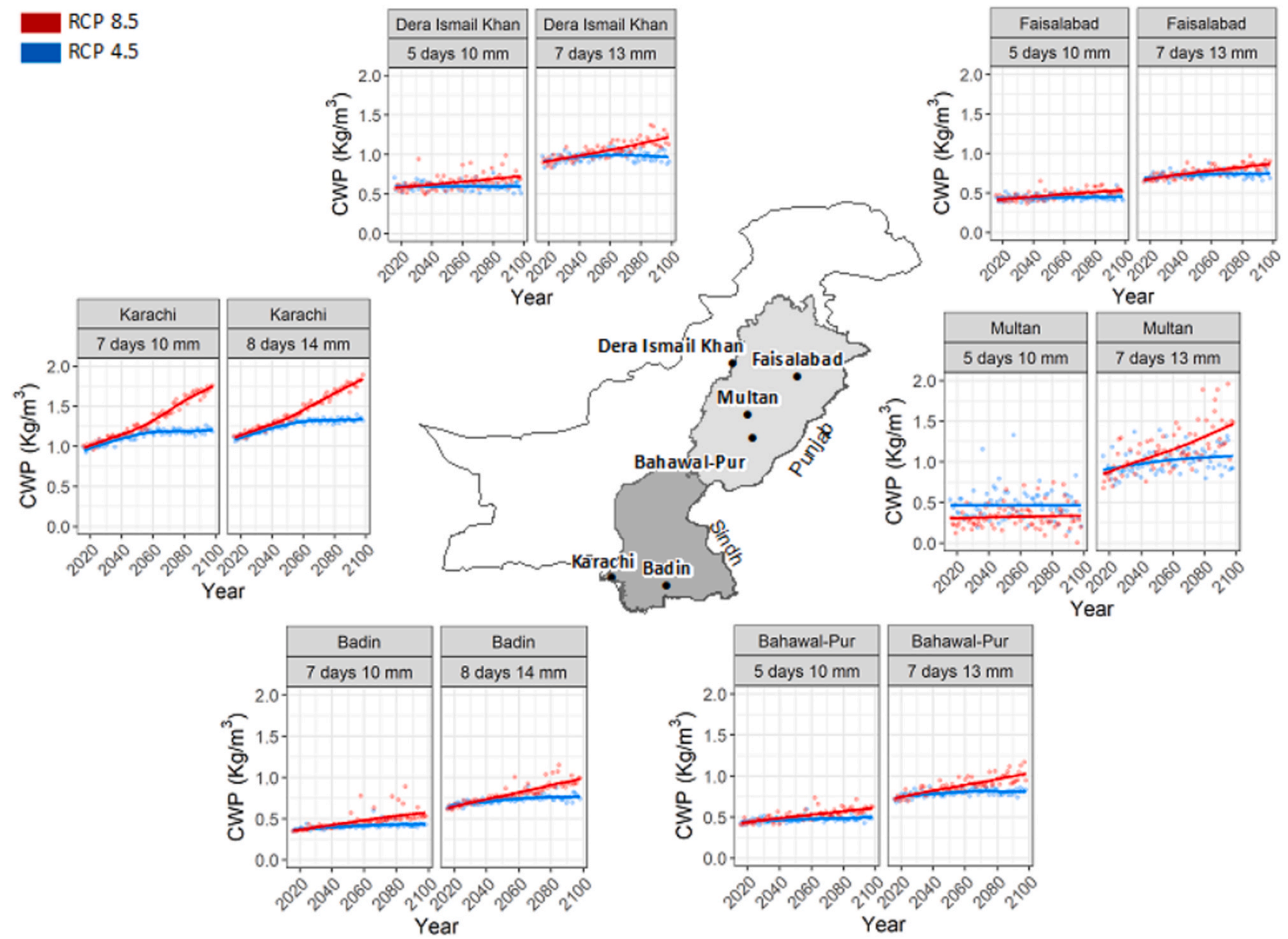

Fig. 10. Projected crop water productivity (CWP) of wheat ( $\mathrm{kg}$ yield $/ \mathrm{m}^{3}$ water evapotranspired) under RCP 4.5 and 8.5 for six locations considered in Sindh and Punjab provinces under different irrigation schedules.

\subsubsection{Yields and crop water productivity}

Wheat yields are expected to remain constant over the 21st century along Dera Ismail Khan (avg. 2.36 ton/ha), Faisalabad (avg. 1.67 ton/ ha) and Bahawal-Pur (avg. 1.65 ton/ha) under frequent and low irrigation schemes (5days- $10 \mathrm{~mm}$; total $270-292 \mathrm{~mm}$ ) for both RCPs (Fig. 9). However, a notable yield increase is depicted when comparing the previous irrigation scheme with less frequent applications but higher amounts (7 days-13 mm; total: $312-325 \mathrm{~mm}$ ), with yields improving as follows: Dera Ismail Khan (avg. 3.97 ton/ha), Faisalabad (avg. 2.80 ton/ ha), and Bahawal-Pur (avg. 2.87 ton/ha). In fact, with similar high atmospheric evaporative demand and $10 \%$ increase between the two irrigation schemes, the percentage of water stress reducing leaf expansion is $76.4 \%$ under 5 days $-10 \mathrm{~mm}$ and $65.3 \%$ under 7 days- $13 \mathrm{~mm}$, average of both RCPs. As a result, the cumulative amount of water transpired increased (Fig. 8), translating into a higher water productivity (Fig. 10). Along the Sindh province, e.g. Karachi, yields are also expected to rise from 4.40 ton/ha to $5.17(+17.5 \%)$ and 6.50 ton/ha $(+47.7 \%)$ under RCP 4.5 and 8.5, respectively, when the 2010-2019 and 2080-2099 periods are compared.

Regarding the crop water productivity (CWP), all of the targeted locations are expected to experience an increase in CWP; except Multan under the irrigation schedule 5 days $-10 \mathrm{~mm}$. The station reporting the highest CWP is Karachi under RCP 8.5 and irrigation schedule 8 days$14 \mathrm{~mm}$, with a CWP increase from $1.11 \mathrm{~kg} / \mathrm{m}^{3}$ to $1.79 \mathrm{~kg} / \mathrm{m}^{3}$ respectively from 2010-2019 to 2090-2099 (Fig. 10).

\subsection{Sugarcane}

\subsubsection{Soil evaporation and transpiration}

The soil evaporation (SE) values are higher (396 mm on avg. for the complete time-series) in the Punjab province, under RCP 8.5 and irrigation schedule 7 days- $29 \mathrm{~mm}$ when compared to the Sindh province ( $281 \mathrm{~mm}$ on avg. for the complete time-series) for RCP 4.5 and irrigation schedule 10 days- $41 \mathrm{~mm}$ (Fig. 11). There is an increase in SE particularly towards the northern parts of the country (Dera Ismail Khan and Faisalabad), with the highest rate of SE increase under RCP 8.5 when compared to RCP 4.5 .

For transpiration $(\mathrm{T})$, higher $\mathrm{T}$ values are projected in the Sindh province (674 $\mathrm{mm}$ on avg. for the complete time series) when compared to the Punjab province (573 $\mathrm{mm}$ on avg. for the complete time series) for both irrigation schedules and RCPs (Fig. 12). However, spatial differences on $\mathrm{T}$ trends were observed, particularly among southernmost (Sindh province) and northernmost areas (Punjab province). While Karachi and Badin will experience a decrease in $\mathrm{T}$ overtime from the start of the simulations, all Punjab sites, except Bahawal-Pur, report an exponential increase in $\mathrm{T}$ up until 2080. Increasing $\mathrm{T}$ trends is tightly related to temperature increase during Jan-Mar. The thermal increase along the Punjab province coincides with the mid-growing stages of sugarcane (if sown in November as done herein) when Kc are highest (1.25), consequently enhancing $\mathrm{T}$ rates. On the other hand, temperatures along Karachi and Badin remain similar over time (Fig. 4) and, therefore, $\mathrm{T}$ rates slightly decrease rather than increase (Fig. 12). AquaCrop simulations have shown that sugarcane will be susceptible to increasing temperatures particularly along the Punjab province, where 


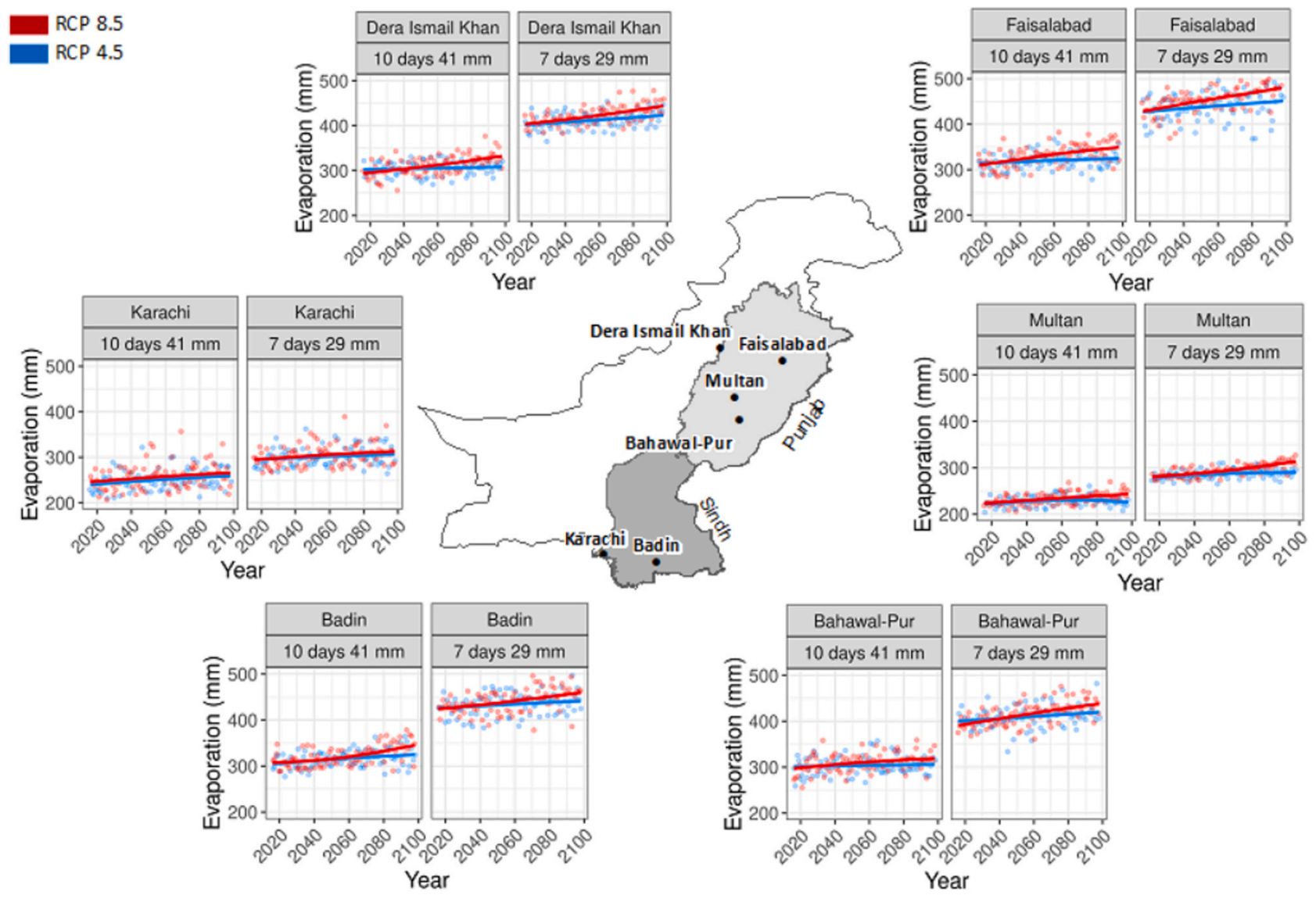

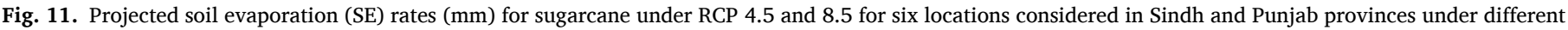
irrigation schedules.

the average temperature stress affecting crop transpiration $\left(\mathrm{Ks}_{\mathrm{Tr}}\right)$ is expected to be of $13.1 \%$ (avg. values for the 2010-2099 period) throughout the growing season.

\subsubsection{Yields and water use efficiency}

Sugarcane yields display a similar behavior to that of transpiration (T) over time across the different locations, RCPs, and irrigation schedules (Fig. 13). This is due to the direct relationship between yields and biomass production which depend on $\mathrm{T}$. While sugarcane yields experience a notable decrease $(-14.7 \%)$ over time along the Sindh province, from 28.6 ton/ha (MNFSR avg. observed values in Karachi between 2006 and 2015) to 24.4ton/ha (simulated values for the period 2090-2099 for the two locations, RCPs and irrigation schedules), yields are projected to increase over the Punjab province. For the latter, sugarcane yields are expected to increase by $13.0 \%$, from 22.2 ton/ha (MNFSR avg. observed values in Multan between 2006 and 2015) to 25.1 ton/ha in 2070-2080 (avg. simulated yield values in the four locations, RCPs and irrigation schedules), afterwards yields are projected to decline. Even though yield trends have a similar behavior in all locations over time and for both RCPs, yields are estimated to be higher $(+8.3 \%)$ under the irrigation schedule 10 days $-41 \mathrm{~mm}$ (861 $\mathrm{mm}$ in total) when compared to 7 days-29 $\mathrm{mm}(870 \mathrm{~mm})$ (Fig. 13).

For the complete time series (2010-2099), the average crop water productivity (CWP) in Sindh province is of 2.38 and of $2.66 \mathrm{~kg} / \mathrm{m}^{3}$ $(+11.8 \%)$ when 7 days $-29 \mathrm{~mm}$ with 10 days- $41 \mathrm{~mm}$ are respectively compared (Fig. 14). A similar pattern is observed over the Punjab province, where the CWP is of 2.47 and $2.86 \mathrm{~kg} / \mathrm{m}^{3}(+17 \%)$ when 7 days $-29 \mathrm{~mm}$ with 10 days- $41 \mathrm{~mm}$ are respectively compared. Overall, the CWP is projected to decrease over time across the Sindh and Punjab provinces, with a greater rate of decrease under RCP 8.5. For instance, the CWP is likely to decline from $2.65 \mathrm{~kg} / \mathrm{m}^{3}$ to $2.48 \mathrm{~kg} / \mathrm{m}^{3}$ (-6.4\%) under RCP 8.5 when the 2010-2019 and 2080-2099 periods are compared for both irrigation schemes.

\section{Discussion}

While the simulations present in this study show that wheat will not be adversely impacted by increasing temperatures and $\mathrm{CO}_{2}$ concentrations if sowing continues to take place on the 1 st of November, negative impacts are expected for sugarcane depending on the time horizon and location. For wheat, as reported in Sections 3.1.2 and 3.3.2, the growing cycle will be shortened by 20-30 days because of an increase in the accumulated heat units during a day (GDD). As a result, heat-stress conditions (31.0 and $35.4{ }^{\circ} \mathrm{C}$ are considered the critical temperature thresholds at anthesis and grain filling phase) occurring in March and April will be avoided (Porter and Gawith, 1999). Hence, the pollination of wheat and the grain filling phase will not be hindered by the exposure to heat-stress conditions. While $51 \%$ of the Indo-Gangetic Plains will be reclassified as heat-stress zones by 2050 (Ortiz et al., 2008), several studies, including this one, suggest a reduction on the duration of the growing season of wheat under changing climatic conditions (Valizadeh et al., 2014). Despite the fact that the grain filling phase will be shortened (Rezaei et al., 2015), the present study reveals that an acceleration of wheat's phenological phases (under irrigated conditions) due to rising temperatures will not result in a reduction of wheat yields in Pakistan. The simulations of the present study show a stabilization of yields over time (Fig. 8) and, therefore, our results contrast other studies acknowledging a $20-31 \%$ decline in yields when sowing occurs in November (Sultana et al., 2009; Ahmad et al., 2015; Khan et al., 2020). This can be explained by the fact that the previous studies do not 

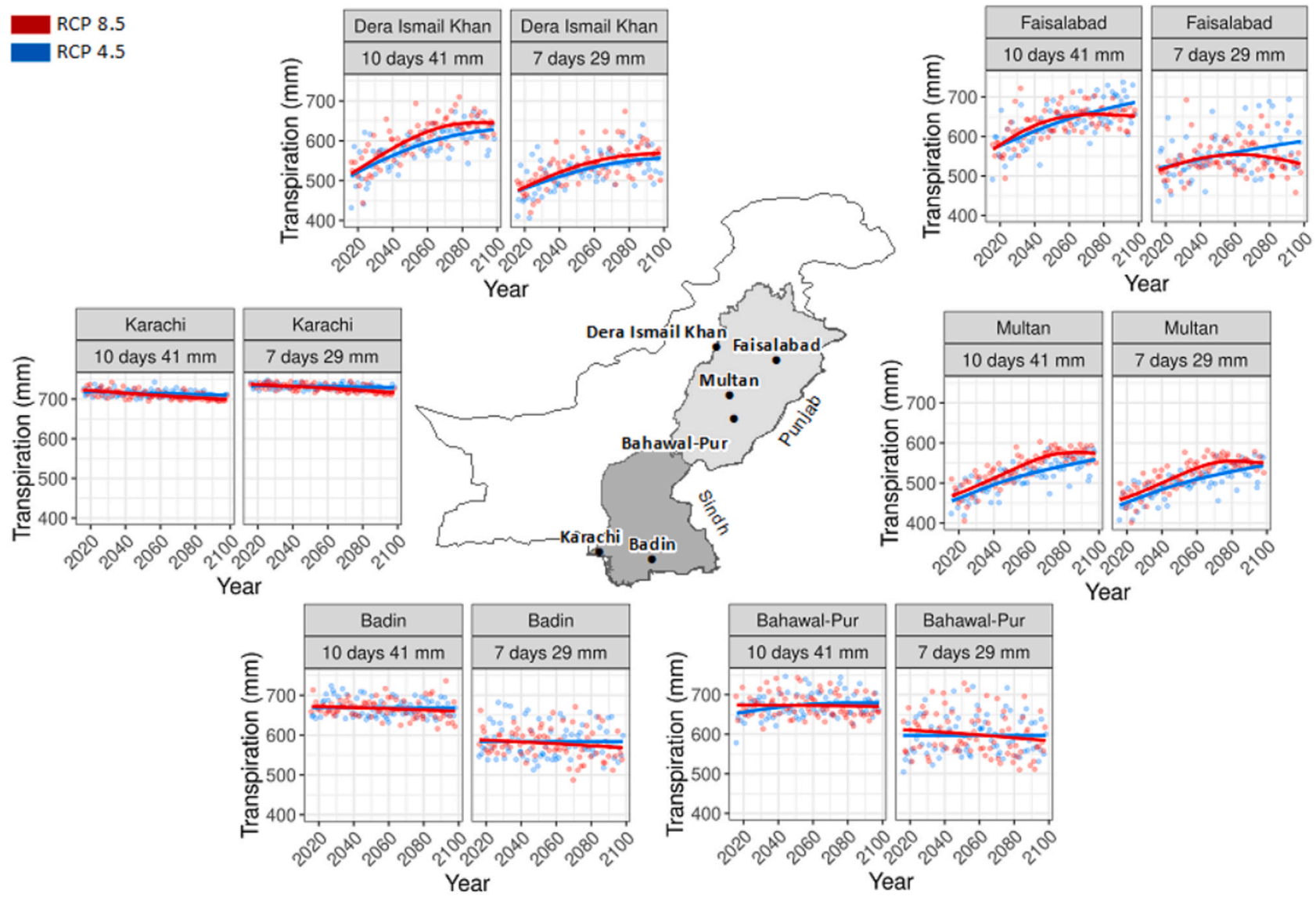

Fig. 12. Projected transpiration (T) rates (mm) for sugarcane under RCP 4.5 and 8.5 for six locations considered in Sindh and Punjab provinces under different irrigation schedules.

thoroughly examine indicators such as GDD in crop development. Nevertheless, the present study is in harmony to that of Janjua et al. (2010) also conducted in Pakistan. The findings of the latter show that in all $\mathrm{CO}_{2}$, temperature and precipitation scenarios, wheat will be positively affected and the production will double by 2060 as compared to the present yield levels.

While sugarcane yields are expected to increase along the Punjab province up until 2080 , a $2.3^{\circ} \mathrm{C}$ increase in mean Tmax between 2020 and 2039 and 2080-2099 periods in central and southernmost parts of the country (Karachi, Badin and Bahawal-Pur) will have a negative impact on sugarcane yields. The findings of this work for the latter locations are in line with those of Afghan and Ijaz (2015), acknowledging a $10 \%$ decrease in sugarcane yields for every $1{ }^{\circ} \mathrm{C}$ increase. Even though AquaCrop simulations show a decline in yields along the Punjab province from mid/end century onwards, the present study shows that the rate of decrease will be lower to that reported by Akbar and Gheewala (2020) in the Punjab province (16\%). A recent publication (Farooq and Gheewala, 2020) on CROPWAT and AquaCrop in Faisalabad and Rahim Yar Khan has shown a similar yield trend to that of this study, where production is expected to increase up until 2080 then decrease by $0.6 \%$ under RCP 8.5 when comparing to the baseline period (1981-2005). In both studies, results revealed a growth in the crop water requirements due to rising soil evaporation and transpiration, with a subsequent increase in irrigation demand. However, the latter study reports much higher irrigation requirements (1740-2145 mm) when sowing between
15/02 and 12/03 in Faisalabad to that of this study when sowing occurs on the 01/09 $(861 \mathrm{~mm})$. An increase in temperature under changing climatic conditions will alter soil evaporation and might cause water stress and as consequence the need to apply higher amounts of water to meet sugarcane's evapotranspiration demand (Hussain et al., 2018). Even though our findings are in line with the latter study, more frequent irrigation (7 days- $29 \mathrm{~mm}$ rather than 10 days $-41 \mathrm{~mm}$ ) will substantially increase the losses derived from direct soil evaporation. Consequently, in order to optimize the use of water resources and increase the yields of sugarcane, less frequent but higher water applications is recommended (10 days- $41 \mathrm{~mm}$ ). This is particularly important across certain regions in Pakistan where agricultural water is used with low efficiency among high-water consuming crops (sugarcane). If promoted, the dual challenge of increasing sugarcane production and farm income while saving water will be achieved.

\section{Conclusion}

Agricultural production is affected by a number of climate factors, including rainfall patterns, temperature rise, change in sowing and harvesting dates, water availability, and evapotranspiration and land suitability. The future crop water requirements (CWP) of wheat and sugarcane in Pakistan are likely to increase with time; nevertheless, water resources can be optimized if appropriate irrigation and planting scheduling under changing climate and environmental conditions are 

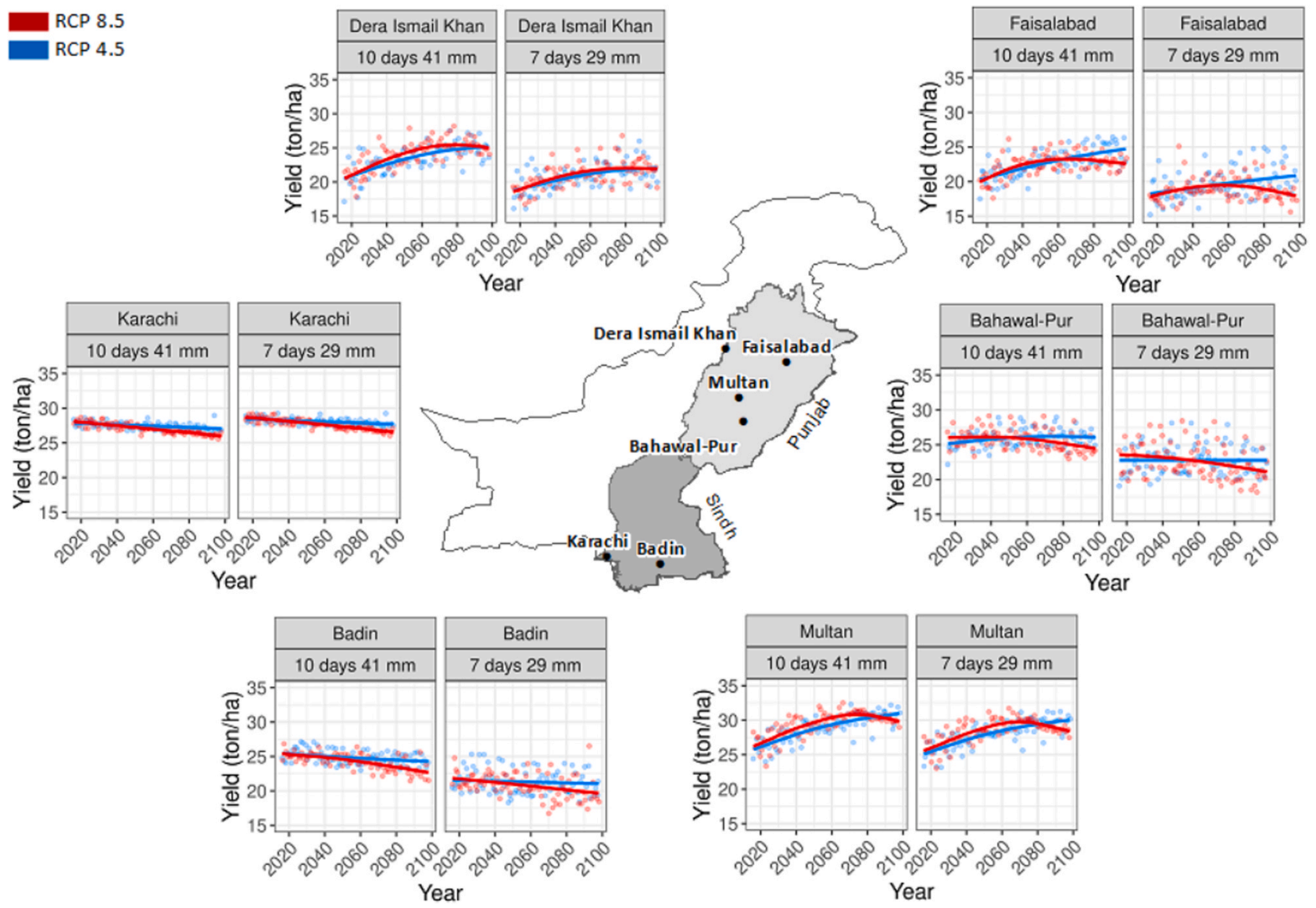

Fig. 13. Projected sugarcane yields (ton/ha) under RCP 4.5 and 8.5 for six locations considered in Sindh and Punjab provinces under different irrigation schedules.

applied. The results of this work can inform medium to long-term national adaptation priority actions for planning in the agriculture sector in Pakistan by enhancing water resource management throughout the country. The results provide decision-makers and project developers with a robust scientific evidence-based for actions related to water allocation and related water policies. This study presents the following conclusions:

- A slight increase in projected precipitation $(+2.7 \mathrm{~mm} / \mathrm{month}$ for Oct-Dec) at early growing stages of wheat will have minimal impact on the performance of the crop. The slight increase in precipitation will be offset by increasing soil evaporation and transpiration rates due to rising temperatures $\left(2.3\right.$ and $4.0^{\circ} \mathrm{C}$ under RCP 4.5 and 8.5 by $2080-2099$ ).

- An increase in the accumulated heat units during a day (GDD) will shorten the growing cycle of wheat by 20-30 days. As a result, the exposure of wheat to heat-stress conditions at anthesis and ripening phase will be reduced. Consequently, we recommend maintaining the current calendars for wheat in the region.

- Wheat yields are expected to remain constant along all study areas, except for Karachi, where yields will likely notably increase by $17.5 \%$ and $47.7 \%$ under RCPs 4.5 and 8.5 , respectively.
- Wheat has higher CWP under less frequent but higher water applications (8 days-14 mm and 7days-13 mm along Sindh and Punjab province, respectively).

- Sugarcane is projected to be adversely affected by increasing temperatures (mean Tmax during Apr-Jun is expected to increase from 40.9 to $43.5^{\circ} \mathrm{C}$ when compared to the 2020-2039 and 2080-2099 periods across the six the locations under both RCPs). As a result, the exposure of sugarcane to heat-stress conditions will be of $13.1 \%$ along the entire growing period. In order to select the optimal growing period for sugarcane, further research needs to be conducted testing different sowing dates and irrigation schedules.

- While transpiration of sugarcane will exponentially increase along the northernmost parts of the country, it will remain constant and/or slightly decrease in central and southernmost areas over time.

- Our results reveal that sugarcane yields will decline from the present onwards in central and southernmost parts of the country; however, northernmost parts will experience a notable increase up until 2080, after which yields will start to decline.

- Compared to wheat, sugarcane will perform better, in terms of CWP, under less frequent but higher volumes of irrigation (10 days-41 mm).

- Overall, AquaCrop was particularly useful to better understand crop's responses to environmental change, identify constraints 

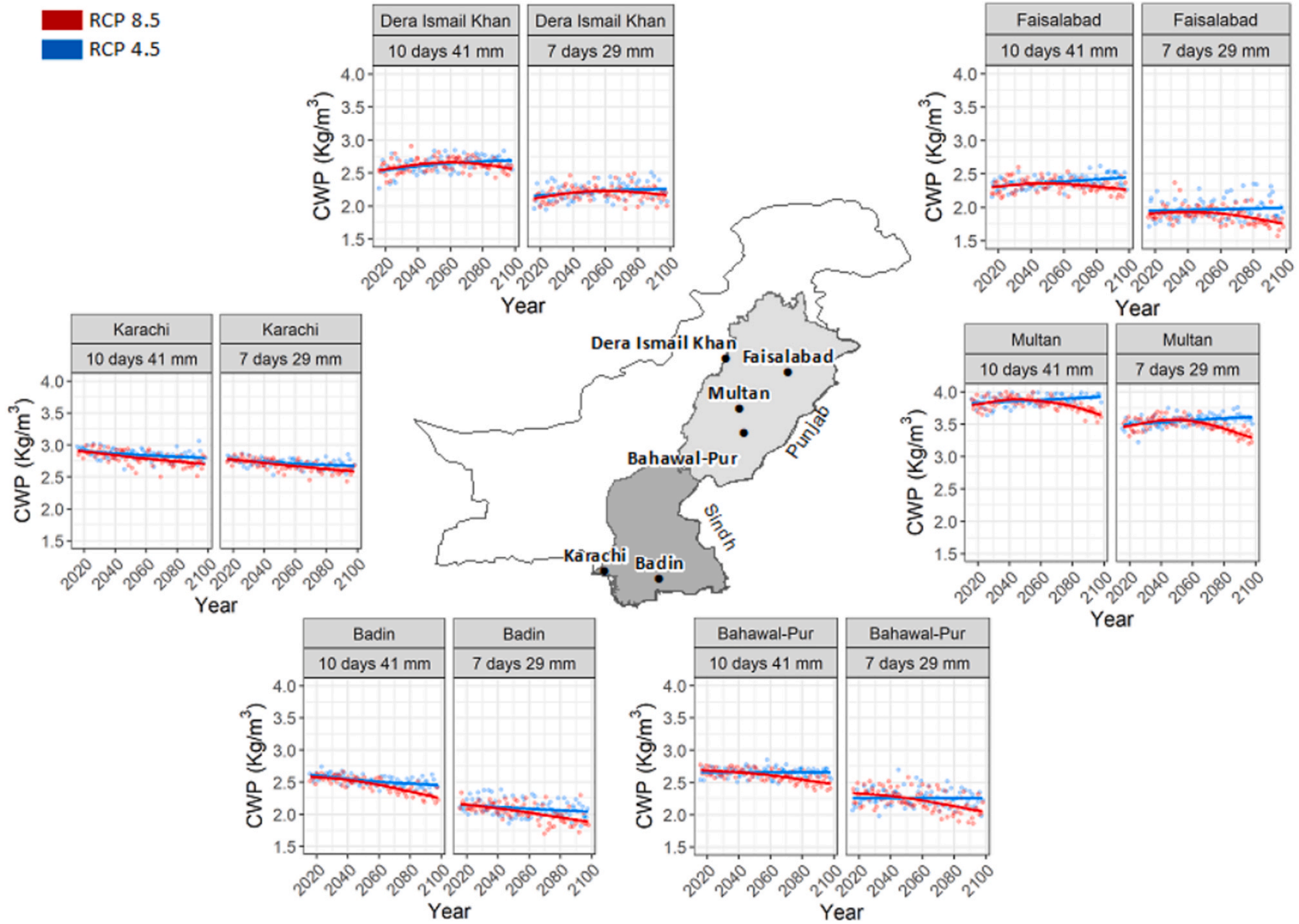

Fig. 14. Projected crop water productivity (CWP) of sugarcane ( $\mathrm{kg}$ yield $/ \mathrm{m}^{3}$ water evapotranspired) under RCP 4.5 and 8.5 for six locations considered in Sindh and Punjab provinces under different irrigation schedules.

to crop production and water productivity, develop irrigation schedules for maximum production, and to study the effect of climate change in a country expected to face increasing food insecurity challenges.

\section{Declaration of Competing Interest}

The authors declare that they have no known competing financial interests or personal relationships that could have appeared to influence the work reported in this paper.

\section{Acknowledgements}

The data collection and analysis for the study was initiated under the formulation of the FAO led Green Climate Fund (GCF) project in Pakistan entitled "Transforming the Indus Basin with Climate Resilient Agriculture and Water Management" and further elaborated by the authors. Meteorological data used in this study was provided by the Pakistan Meteorological Authority (PMD) and guidance on crop parameters was provided by experts from FAO Pakistan. The authors acknowledge colleagues in FAO's investment centre for leading the project formulation, the technical support and inputs from FAO Pakistan and the Ministry of Climate Change in Pakistan, the National Designated Authority for the GCF project. The findings of this study have informed the development of the GCF project and identified areas for further assessment through the implementation.

\section{References}

Adnan, S., Ullah, K., Shouting, G., 2016. Investigations into precipitation and drought climatologies in South Central Asia with special focus on Pakistan over the period 1951-2010. J. Clim. 29 (16), 6019-6035.

Afghan, S., Ijaz, M.W., 2015. Climate change impact on sugar industry of Pakistan: an overview. Pak. Sugar J. 30, 17-23.

Ahmad, A., Ashfaq, M., Rasul, G., Wajid, S.A., Khaliq, T., Rasul, F., Naqvi, S.A.A., (2015). Impact of climate change on the rice-wheat cropping system of Pakistan. In: Handbook of Climate Change and Agroecosystems: The Agricultural Model Intercomparison and Improvement Project Integrated Crop and Economic Assessments, Part 2, pp. 219-258.

Akbar, H., Gheewala, S.H., 2020. Effect of climate change on cash crops yield in Pakistan. Arab. J. Geosci. 13, 390.

Allen, R.G., Pereira, L.S., Raes, D., Smith, M., 1998. In Crop EvapotranspirationGuidelines for Computing Crop Water Requirements-FAO Irrigation and Drainage. FAO, Rome (paper 56).

Andarzian, Bannayan, M., Steduto, P., Mazraeh, H., Barati, M.E., Barati, M.A., Rahnama, A., 2011. Validation and testing of the AquaCrop model under full and deficit irrigated wheat production in Iran. Agric. Water Manag. 100 (1), 1-8.

Bowes, G., 1991. Growth at elevated $\mathrm{CO}_{2}$ : photosynthetic responses mediated through Rubisco. Plant Cell Environ, 14 (8), 795-806.

Chaudhry, A., Mahmood, G., Rasul, M., Afzaal., 2009. Climate Change Indicators of Pakistan. Pakistan Meteorological Department, Technical Report No. PMD-22/2009.

Clarke, L., Edmonds, J., Jacoby, H., Pitcher, H., Reilly, J., Richels, R.,2007. Scenarios of Greenhouse Gas Emissions and Atmospheric Concentrations.

Dee, D.P., Uppala, S.M., Simmons, A.J., Berrisford, P., Poli, P., Kobayashi, S., Vitart, F., 2011. The ERA-Interim reanalysis: configuration and performance of the data assimilation system. Q. J. R. Meteorol. Soc. 137 (656), 553-597.

Du, H., Alexander, L.V., Donat, M.G., Lippmann, T., Srivastava, A., Salinger, J., Rusticucci, M., 2019. Precipitation from persistent extremes is increasing in most regions and globally. Geophys. Res. Lett. 46 (11), 6041-6049.

Eckstein, D., Künzel, V., Schäfer, L., Winges, M.,2019. Global climate risk index 2020 Germanwatch. https://germanwatch.org/sites/germanwatch.org/files/20-2-01e\% 20Global, 20. 
FAO 2016. AQUASTAT Main Database, Food and Agriculture Organization of the United Nations (FAO). Website accessed on 10/08/2020. http://www.fao.org/aquastat/en /databases/maindatabase/.

FAO 2018. FAOSTAT Data: Crops. Data accessed on 10/08/2020. http://www.fao.org/ faostat.

Farooq, N., Gheewala, S.H., 2020. Assessing the impact of climate change on sugarcane and adaptation actions in Pakistan. Acta Geophys. 68 (5), 1489-1503.

Gutiérrez, J.M., San-Martín, D., Brands, S., Manzanas, R., Herrera, S., 2013. Reassessing statistical downscaling techniques for their robust application under climate change conditions. J. Clim. 26 (1), 171-188. https://doi.org/10.1175/JCLI-D-11-00687.1. URL http://dx.doi.org/10.1175/JCLI-D-11-00687.1.

Helsel, D.R., Hirsch, R.M., 2002. Statistical Methods in Water Resources, Vol. 323. US Geological Survey, Reston, VA.

Hijioka, E., Lin, JJ., Pereira, RT. Corlett, X., Cui, GE., Insarov, RD., Lasco, E., Lindgren, A. Surjan 2014. Asia, volume Climate Change 2014: Impacts, Adaptation, and Vulnerability. Part B: Regional Aspects. Contribution of Working Group II to the Fifth Assessment Report of the Intergovernmental Panel on Climate Change, chapter 24, pages 1327-1370. University of Cambridge Press.

Houze Jr., R.A., Rasmussen, K.L., Medina, S., Brodzik, S.R., Romatschke, U., 2011. Anomalous atmospheric events leading to the summer 2010 floods in Pakistan. Bull. Am. Meteorol. Soc. 92 (3), 291-298.

Hussain, J., Khaliq, T., Ahmad, A., Akhter, J., Asseng, S., 2018. Wheat responses to climate change and its adaptations: a focus on arid and semi-arid environment. Int. J. Environ. Res. 12 (1), 117-126.

Irvine, J.E.,1983. Sugarcane. In: Proceedings of the Symposium on Potential Productivity of Field Crops under Different Environments (pp. 361-381). Los Baños^ ePhilippines Philippines: IRRI.

ISRIC 2020. Soil Grids Data: Data Download. https://files.isric.org/soilgrids/.

Janjua, P.Z., Samad, G., Khan, N.U., Nasir, M., 2010. Impact of climate change on wheat production: a case study of Pakistan. Pak. Dev. Rev. 49, 799-822.

Khan, M, et al., 2020. Improving resource use efficiencies of sugarcane at farmer field under arid environment. International Journal of Agriculture and Biology.

Kimball, B.A., 1983. Carbon dioxide and agricultural yield: an assemblage and analysis of 430 prior observations 1. Agron. J. 75 (5), 779-788.

Liancourt, P., Spence, L.A., Boldgiv, B., Lkhagva, A., Helliker, B.R., Casper, B.B., Petraitis, P.S., 2012. Vulnerability of the northern Mongolian steppe to climate change: insights from flower production and phenology. Ecology 93 (4), 815-824.

Macaigne, P., Isaque, W., Heng, L., 2018. Modelling the expansion of salinity in cultivated areas of Pakistan. EGUGA 5316.

Malik, A., Shakir, A.S., Ajmal, M., Khan, M.J., Khan, T.A., 2017. Assessment of AquaCrop model in simulating sugar beet canopy cover, biomass and root yield under different irrigation and field management practices in semi-arid regions of Pakistan. Water Resour. Manag. 31 (13), 4275-4292.

Manzanas, R., Fiwa, L., Vanya, C., Kanamaru, H., Gutiérrez, J.M., 2020. Statistical downscaling or bias adjustment? A case study involving implausible climate change projections of precipitation in Malawi. Clim. Change 162 (3), 1437-1453.

Ortiz, R., Sayre, K.D., Govaerts, B., Gupta, R., Subbarao, G.V., Ban, T., Reynolds, M., 2008. Climate change: can wheat beat the heat? Agric. Ecosyst. Environ. 126 (1-2), 46-58.

Poorter, H., 1993. Interspecific variation in the growth response of plants to an elevated ambient $\mathrm{CO} 2$ concentration. $\mathrm{CO}_{2}$ and Biosphere. Springer, Dordrecht, pp. 77-98.

Porter, J.R., Gawith, M., 1999. Temperatures and the growth and development of wheat: a review. Eur. J. Agron. 10 (1), 23-36.

Poulter, B., Pederson, N., Liu, H., Zhu, Z., D’Arrigo, R., Ciais, P., Piao, S., 2013. Recent trends in Inner Asian forest dynamics to temperature and precipitation indicate high sensitivity to climate change. Agric. For. Meteorol. 178, 31-45.
Preisendorfer, R.W., Mobley, C.D., 1988. Principal component analysis in meteorology and oceanography. Dev. Atmos. Sci. 17.

Qureshi, S.A., Madramootoo, C.A., Dodds, G.T., 2002. Evaluation of irrigation schemes for sugarcane in Sindh, Pakistan, using SWAP93. Agric. Water Manag. 54 (1), 37-48.

Raes, D., Steduto, P., Hsiao, T.C., Fereres, E., 2018. Chapter 2: Users guide. AquaCrop version 6.0-6.1. Reference Manual. Food Agricultural Organization (FAO), Rome, pp. 2-302.

Rezaei, E.E., Webber, H., Gaiser, T., Naab, J., Ewert, F., 2015. Heat stress in cereals: mechanisms and modelling. Eur. J. Agron. 64, 98-113.

Riahi, K., Grübler, A., Nakicenovic, N., 2007. Scenarios of long-term socio-economic and environmental development under climate stabilization. Technol. Forecast. Soc. Change 74 (7), 887-935.

Richey, A.S., Thomas, B.F., Lo, M.H., Reager, J.T., Famiglietti, J.S., Voss, K., Rodell, M., 2015. Quantifying renewable groundwater stress with GRACE. Water Resour. Res. 51 (7), 5217-5238.

Sandhu, S.S., Mahal, S.S., Kaur, P., 2015. Calibration, validation and application of AquaCrop model in irrigation scheduling for rice under northwest India. J. Appl. Nat. Sci. 7 (2), 691-699.

Sanghera, G.S., Malhotra, P.K., Singh, H., Bhatt, R., 2019. Climate change impact in sugarcane agriculture and mitigation strategies. Harnessing Plant Biotechnology and Physiology to Stimulate Agricultural Growth, 99-115.

Sultana, H., Ali, N., Iqbal, M.M., Khan, A.M., 2009. Vulnerability and adaptability of wheat production in different climatic zones of Pakistan under climate change scenarios. Clim. Change 94 (1-2), 123-142.

Tariq, A., Tabasam, N., Bakhsh, K., Ashfaq, M., Hassan, S., 2014. Food security in the context of climate change in Pakistan. Pak. J. Commer. Soc. Sci. (PJCSS) 8 (2), $540-550$.

Thompson, G.D.,1978. The production of biomass by sugarcane. In Proceedings of the South African Sugar Technologists' Association (No. 52, pp. 180-187).

TWB2016. The Indus Basin of Pakistan: the Impacts of Climate Risks on Water and Agriculture. http://documents1.worldbank.org/.

UAF 2020. University of Agriculture Faisalabad: Survey of Weeds Infesting the Arable Fields in the Punjab and Development of Judicious Weed Control Strategies. htt p://uaf.edu.pk/uaf_research/prj_42.html.

UN, 2019. Department of Economics and Social Affairs: population dynamics. World Population Prospects 2019. https://population.un.org/wpp/.

Valizadeh, J., Ziaei, S.M., Mazloumzadeh, S.M., 2014. Assessing climate change impacts on wheat production (a case study). J. Saudi Soc. Agric. Sci. 13 (2), 107-115.

Vanuytrecht, E., Raes, D., 2011. Assessment of the ' $\mathrm{CO}_{2}$ fertilization effect'on crops with the AquaCrop model. Geophys. Res. Abstr. 13, EGU2011-EGU5917.

Wahid, A., Close, T.J., 2007. Expression of dehydrins under heat stress and their relationship with water relations of sugarcane leaves. Biol. Plant. 51 (1), 104-109.

Wang, Z., Yang, S., Duan, A., Hua, W., Ullah, K., Liu, S., 2019. Tibetan Plateau heating as a driver of monsoon rainfall variability in Pakistan. Clim. Dyn. 52 (9-10), 6121-6130.

WFP2018. Pakistan country brief. Data available at: https://www.wfp.org/countries /pakistan.

WMO2020. Global State of Climate in 2020.

Zhao, D., Li, Y.R., 2015. Urban particle size distributions during two contrasting dust events originating from Taklimakan and Gobi Deserts. Environ. Pollut. 207, 107-122 (Barking, Essex: 1987).

Zorita, E., Hughes, J.P., Lettemaier, D.P., von Storch, H., 1995. Stochastic characterization of regional circulation patterns for climate model diagnosis and estimation of local precipitation. J. Clim. 8 (5), 1023-1042. 